Disability status, individual variable pay, and pay satisfaction:

Does relational and institutional trust make a difference?

\author{
Dr. Amanda Shantz \\ Reader \\ Greenwich Business School, University of Greenwich \\ Old Royal Naval College, 30 Park Row \\ London, SE10 9LS, United Kingdom \\ Phone: 02083319032 Fax: 02083318145 \\ Email: as9032w@gre.ac.uk \\ Dr. Jing Wang \\ Associate Professor \\ School of Human Resource Management, York University \\ School of Economics \& Management, Tongji University \\ 150Q Atkinson Bldg, 4700 Keele Street \\ Toronto, Ontario, Canada, M3J 1P3 \\ Phone: 4167362100 Ext. 44663 Fax: 4167365188 \\ Email: jingwan@yorku.ca \\ Dr. Amina R. Malik \\ Assistant Professor \\ School of Business, Trent University \\ 55 Thornton Road, Oshawa, Ontario L1J 5 Y1 \\ Phone: 9054355100 ext 5067 Fax: 9054355101 \\ Email: aminamalik@trentu.ca
}

Published in Human Resource Management 2017 


\begin{abstract}
Although prior research suggests that disabled employees have different needs in the context of some human resource management (HRM) practices, we know little about their reactions to reward systems. We address this gap in the literature by testing a model using the 2011 British Workplace Employee Relations Survey (disabled employees $n=1,251$; nondisabled employees $n=9,959$; workplaces $n=1806$ ) and find that disabled employees report lower levels of pay satisfaction than nondisabled employees, and when compensated based on individual performance, the difference in pay satisfaction is larger. We suggest that relational (derived from trust in management) and institutional (derived from firm-wide policies and HRM practices, both intended to provide equitable treatment to disabled employees) forms of trust play important roles. The results of multilevel analyses show that when trust in management is high, the difference in pay satisfaction under variable pay is reduced. We find just the opposite for employees who work in organizations with a formal disability policy but without supportive HRM practices; the gap in pay satisfaction is exacerbated. However, the combination of the presence of a firm-wide policy and HRM practices reduced the difference in pay satisfaction. Implications of the findings for theory, future research, and management practice are discussed.
\end{abstract}

Keywords: disability policy; disability status; HRM practices; individual variable pay; institutional trust; multilevel modelling; pay satisfaction; relational trust; trust in management 


\section{Disability status, individual variable pay, and pay satisfaction: Does relational and institutional trust make a difference?}

A priority for organizations today is attracting, engaging, and retaining a diverse workforce (e.g., Konrad, Yang, \& Maurer, 2016). This is because increased diversity can lead to a better understanding of local markets and customers, a greater ability to attract and retain talent, increased creativity, problem solving, and flexibility for organizations (e.g., Cox \& Blake, 1991; Subeliani \& Tsogas, 2005). Although numerous scholars in human resource management (HRM) have examined work-related factors that lead various demographic groups to be satisfied at work (Ariss, Vassilopoulou, Özbilgin, \& Game, 2013; Cooke \& Xiao, 2014; Kooij, Jansen, Dikkers, \& De Lange, 2010), far fewer have focused on those who are disabled, or are impaired in a way that limits their activity, yet allows for gainful employment (Stone \& Colella, 1996; Theodorakopoulos \& Budhwar, 2015). Understanding factors that are associated with the satisfaction of disabled employees is important given that disabled individuals constitute an underutilized labor pool, they have the potential to bring about the aforementioned benefits of diversity, and in most cases, are just as able and motivated to be successful at work relative to their nondisabled counterparts (Ali, Schur, \& Blanck, 2011; Lengnick-Hall, Gaunt, \& Kulkarni, 2008; Schur, Nishii, Adya, Kruse, Bruyere, \& Blanck, 2014).

Despite this potential, research shows that disabled employees earn less than equally qualified, nondisabled employees (Gunderson \& Lee, 2016; Hallock, Jin, \& Barrington, 2014; Longhi, Nicoletti, \& Platt, 2012). The starting point of this research therefore, is an examination of disabled versus nondisabled employees' pay satisfaction, that is, the "amount of overall positive or negative affect (or feelings) that individuals have toward their pay" (Miceli \& Lane, 1991, p. 246). We expect that disabled employees have lower levels of pay satisfaction because, 
according to equity theory, individuals are dissatisfied when their work inputs (i.e. education, tenure, performance) are incommensurate with their work outcomes (i.e. income), compared to similar (nondisabled) others (Adams, 1963).

A potential key to facilitating the pay satisfaction of disabled employees is specific HRM practices, such as reward systems. In the present study, we examine the attitudinal responses of disabled versus nondisabled employees to a specific type of reward practice: individual variable pay. Disregarding disabled employees' reports of HRM practices and their pay satisfaction may expose organizations to legal action, given that it is illegal in most countries to discriminate against a person because of a disability. Further, pressure is mounting for organizations to report disability-related statistics in non-financial business reports in order to comply with legal regulations and/or to showcase socially responsible behavior (e.g., Equal Employment Opportunity Commission, 2016; Department for Business, Innovation and Skills, 2016; European Commission, 2014). Disabled employees who are dissatisfied are likely to leave their organizations, thereby casting a negative light on them. Furthermore, paying attention to the unique needs of disabled employees is likely to contribute to a diversity climate which is positively associated with organizational commitment, identification and retention for all employees (e.g., Gonzalez \& DeNisi, 2009). In short, organizations have a vested interest - aside from "doing the right thing" - to ensure that disabled employees respond positively to their pay.

An additional reason that we focus on disabled employees' attitudinal reaction to individual variable pay is because there is theoretical reason to believe that disabled employees may respond differently to individual variable pay compared to nondisabled employees. Theory and research on factors affecting the treatment of disabled employees posit that disabled people tend to be negatively stereotyped and therefore may experience discrimination in performance 
evaluations (Legnick-Hall et al., 2008; Smith, Webber, Graffam, \& Wilson, 2004; Stone \& Colella, 1996). Consequently, disabled employees may believe that individual variable pay systems are unfair and report lower satisfaction with their pay.

However, there may be factors in the work environment that mitigate against the negative relationship between individual variable pay and pay dissatisfaction. Identifying these factors is crucial for organizations who wish to employ, engage, and retain disabled employees. We posit that two forms of trust might make a difference. The first, relational trust, refers to expectations that another party will act in good faith (Rousseau, Sitkin, Burt, \& Camerer, 1998; Sitkin \& Roth, 1993). We develop theoretical arguments that an indication of relational trust - trust in management - may narrow the gap in pay satisfaction between disabled and nondisabled employees under variable pay. This is because disabled employees who trust in management believe that the system that underpins variable pay allocation is fair.

The second form of trust is called institutional trust, and it is based on expectations that another party will abide by formal policies and practices that protect those in the relationship (Rousseau et al., 1998; Sitkin \& Roth, 1993). In the present study, this form of trust is operationalized in two ways: the presence of (1) a firm-level policy and (2) HRM practices, both of which are aimed at ensuring that disabled employees are treated fairly. A distinction between policy and practice is imperative, as a disability-related policy without supporting HRM practices is likely to be insufficient, and may even backfire (Hill, 2009; Hoque \& Noon, 2004). This is because the organizational rhetoric does not match the realities in practice. However, when HRM practices are in place to support the policy, then our model predicts that the gap in pay satisfaction under variable pay will decrease. Figure 1 depicts our theoretical model. 


\section{INSERT FIGURE 1 ABOUT HERE}

This study presents a number of contributions to the literature. We examine, for the first time, employee responses to a specific HRM practice - individual variable pay - by disability status, thereby addressing a call to understand diverse employees' reactions to HRM practices (Theodorakopoulos \& Budhwar, 2015). Moreover, this study serves as a contribution because it examines the moderating roles of two forms of trust. This advances three lines of scholarly thought. First, the bulk of research on trust in organizational settings examines trust solely at the micro-level (Bachmann, 2011; Fuglsang \& Jagd, 2015) and the underlying assumption is that "more is better." In the present study, we examine both the micro and macro levels, and we present theoretical arguments that policies that aim to build institutional trust may not always lead to their intended outcomes, particularly in the absence of aligned HRM practices. Second, this study advances theoretical models of disability management. Although Stone and Colella's (1996) theoretical framework includes formal policy as a positive predictor of the fair treatment of disabled employees, very little research has examined disabled employees' responses to policy, or considered that policy may backfire. Finally, the (in)effectiveness of formal policy is also of great interest to HRM scholarship, as theoretical models imply that the benevolent intentions underpinning some policies translate into positive outcomes (e.g., Bowen \& Ostroff, 2004; Guest, 1987), which may not always be the case. Our research sends a particularly strong message to practitioners. We show a way for organizations to optimize the benefits of individual variable pay, while increasing the likelihood that all employees - regardless of disability - are satisfied with their pay. 


\section{Disability status and pay satisfaction}

Equity theory holds that when employees' inputs (i.e. education, skills, performance) do not match their outcomes (i.e. income) in relation to comparable others, individuals develop a sense of unfairness and become dissatisfied (Adams, 1963). Research shows that disabled employees earn less income relative to their nondisabled counterparts, even after controlling for variables such as quality of the job, tenure and actual performance (Gunderson \& Lee, 2016; Hallock et al., 2014; Longhi et al., 2012). Moreover, the gap in income between disabled and nondisabled employees does not narrow over time (Woodhams, Lupton, Perkins, \& Cowling, 2015). Disabled employees may have lower pay because employers hold persistent stereotypes of disabled people, promoting negative expectations of their abilities and attributes, which in turn, influences performance reviews (e.g., Gunderson \& Lee, 2016; Lengnick-Hall et al., 2008; Ren, Paetzold, \& Colella, 2008). When they have similar inputs (i.e. tenure, performance), but different outcomes (i.e. income) from nondisabled employees, disabled employees are likely to be dissatisfied.

Only two studies, to our knowledge, have examined the effect of disability status on pay satisfaction. Witte, Philips, and Kakela (1998) found that 55 learning-disabled college graduates of one university in Miami were less satisfied with their pay compared with a matched nondisabled control group. McAfee and McNaughton (1997) collected survey responses from 236 disabled employees in the USA; the average pay satisfaction was 3.53 out of 9.0; no

comparison was made with nondisabled employees. We provide a constructive replication using a more recent and larger sample, in a different country, controlling for important variables that may influence this relationship (i.e. income, tenure, organization size etc.), with a comparison of 
nondisabled employees. Based on equity theory and corroborating empirical research, we hypothesize the following:

Hypothesis 1: Disabled employees are less satisfied with their pay compared to nondisabled employees.

\section{The moderating role of individual variable pay}

Individual variable pay, by definition, refers to pay that is contingent on individual performance. Although variable pay includes a variety of types of incentives, including piecerate, gainsharing, profit sharing, stock plans and other hybrids (Lawler, 2000), in the present study, we focus on pay based on individual performance or output. Moreover, we focus on employees' subjective reports of individual variable pay, rather than firm-level reports of variable pay. This is because HRM practices are likely to have consequences for employees' attitudes to the extent that they are perceived by employees (Bowen \& Ostroff, 2004; Kehoe \& Wright, 2010) and research shows that employees' perceptions of HRM practices vary significantly from managerial reports of them (Liao, Toya, Lepak, \& Hong, 2009).

Proponents of individual variable pay programs argue that they offer organizations a way to increase motivation and performance, and attract and retain high performers. Hence, it comes as no surprise that they are used by $88 \%$ of organizations in the USA, $80 \%$ in Canada, and $85 \%$ in the United Kingdom (Hewitt Salary Increase Survey, 2009). Woodhams et al. (2015) pointed out that an underlying assumption is that individual variable pay systems are beneficial to all employees, or at least they are believed to have a neutral impact in relation to pay differentials between minority and nonminority groups. This is because in a meritocratic organization, each employee is judged on his or her achievements and efforts, regardless of non-job related individual factors (Castilla \& Benard, 2010). Ceteris paribus, individual variable pay systems 
should lead employees to believe that they are treated in a fair and consistent manner. However, the claim that individual variable pay systems are blind to individual differences, such as disability status, is highly suspect.

Our arguments are based on the fact that, in most cases, supervisors play an instrumental role in measuring the performance of employees, typically by way of a performance appraisal (Elvira \& Graham, 2002; Rynes, Gerhart, \& Parks, 2005). This may be problematic, as research shows that there is variability in employee beliefs regarding the validity of the assessment method used by managers to determine the distribution of individual variable pay (e.g., Gupta, 1980). Indeed, employees often believe that factors aside from performance, such as seniority, nepotism, discrimination, and/or politics, are responsible for how managers calculate individual variable pay (Gupta \& Jenkins, 1996; Gupta \& Shaw, 1998).

These beliefs are not unfounded. Theoretical models of pay decision-making emphasize that rather than recalling specific, observable behaviors, managers tend to recall an overall impression of an employee (e.g., DeNisi \& William, 1998). In doing so, managers employ a number of cognitive schemas in making judgements about performance. Personal characteristics and observed behaviors are used to place employees into categories, and information that is inconsistent with the category is discounted whereas more weight is placed on information that confirms it. As Campbell and Lee (1988, p. 305) stated, “once categorized, the employee's appraisal is as much a function of the evaluator's belief about how a typical individual in that category performs as it is a function of his or her actual performance.” Despite their popularity, individual variable pay schemes have been criticized in relation to their fairness, since their subjectivity gives expression to pre-existing stereotypes (e.g., Castilla \& Benard, 2010; Elvira \& Graham, 2002). 
Supervisors' reliance on stereotypes may be especially pronounced for employees who are disabled. To the extent that disability status is a salient personal characteristic, it is used as a basis for categorization (Colella, DeNisi, \& Varma, 1997). Although equality legislation in the UK (where the data for our study is sourced) has brought about more positive attitudes toward disabled people, negative public perceptions are still pervasive. For instance, Aiden and McCarthy (2014) reported that two-thirds of the UK population felt uncomfortable talking to disabled people and Staniland (2011) found that nearly 8 out of 10 respondents in the UK felt that there is either a lot or a little prejudice toward disabled people.

Studies that have been conducted in the work domain show similar results; nondisabled individuals hold negative stereotypes about disabled individuals (e.g., incompetent, needy, embittered; Colella, 1996) and employers tend to believe that disabled employees perform less well than their nondisabled counterparts (Legnick-Hall et al., 2008; Smith et al., 2004) and have limited job skills (Jones, Gallagher, Kelley, \& Massari, 1991; Legnick-Hall et al., 2008). Disabled employees may also be perceived as lacking person-job or person-organization fit, given that they are stereotyped as being unsuitable or incompetent for the job (Colella \& Varma, 1999; Ren et al., 2008). After realizing these misperceptions, disabled employees may believe that their performance evaluation and pay are unfair. Consistent with the tenants of equity theory (Adams, 1963), the perception of injustice is likely exacerbated under individual variable pay because disabled employees' input-output ratio is larger than comparable nondisabled others, causing an increase in pay dissatisfaction.

Another reason that variable pay may exacerbate the relationship between disability status and pay satisfaction is that disabled employees may view the entire pay system regardless of management's direct involvement in evaluating their performance - as biased 
because it was created by more powerful, nondisabled people. Feminist theory suggests daily procedures and decisions lead to the development of hierarchies in which power lines based on gender, class, race, and disability are continuously reinforced through their reproduction (Acker, 1990; Morris, 1991; Bê, 2012). The structuring persists through workplace practices that are embedded in unequal power divisions where the "ideal" organizational member (strong, courageous, forceful, virile, etc.) always wins (Kanter, 1977). The "micro processes and micro practices that are 'underneath' and constitutive of macro-social structural arrangements' perpetuate the status quo" (Calas \& Smircich, 1996, p. 228). In adopting this lens to disability, the same processes may occur in that the reward system, even if it is deemed entirely "objective" by those who are nondisabled, may lead disabled employees to believe that they are at a disadvantage, especially when the reward system was not developed with disabled employees' unique needs in mind, or when disabled employees are not provided with the requisite reasonable adjustments. Hence, we hypothesize the following:

Hypothesis 2: Individual variable pay moderates the relationship between disability status and pay satisfaction, such that the difference in pay satisfaction between disabled and nondisabled employees is larger with variable pay.

\section{Does relational and institutional trust make a difference?}

Trust is defined as "a psychological state comprising the intention to accept vulnerability based upon positive expectations of the intentions or behavior of another" (Rousseau et al., 1998, p. 395). Scholars distinguish between two forms of trust. First, relational trust derives from repeated, positive interactions between two parties which give rise to positive emotions, such as care and concern. It is characterised by the exchange of valuable resources and high expectations 
of the other party. The result is normally mutual loyalty and support (e.g., Rousseau et al., 1998; Sitkin \& Roth, 1993; Zucker, 1986).

Second, institutional trust refers to expectations that rely on formal controls, including formalized policies and practices. Whether instruments designed to increase institutional trust lead to wholly positive outcomes is debatable. On the one hand, institutional policies and practices can serve as a springboard for the creation of trust by signalling the values that underlie the rule or procedure. On the other hand, scholars have argued that rules or procedures designed to enhance institutional trust can lead to unintended, negative consequences (Rousseau et al., 1998; Sitkin \& Roth, 1993). In the present study, we argue that a way to understand the conflicting predictions of theory in the context of managing diversity in organisations is to take into account the alignment of policy with related practices. In particular, we propose that organizational policies without supporting HRM practices will be ineffectual in reducing the gap in pay satisfaction. Instead, organizational policies that are equipped with related HRM practices have the potential to narrow the pay-satisfaction gap.

Trust in management. Management is the funnel through which employees receive and interpret HRM practices (e.g., Piening, Baluch, \& Ridder, 2014). In the case of individual variable pay, managers must not only define the required standards of performance and behavior, they must also make decisions about rewards, communicate those decisions, and justify them when asked to do so. Employees who trust management may be more satisfied with their pay under an individual variable pay system because they trust that management is reliable, sincere, honest, and treats employees fairly. In the context of making individual variable pay decisions, management has an important role to play in creating a trusting environment, by providing opportunities for voice, treating employees with respect, and/or showing employees how their 
performance translates into rewards (Chang, 2011; van Dijke, de Cremer, Bos, \& Schefferlie, 2009). Farndale and Kelliher (2013) found that employees who trust management are more likely to perceive that their manager treats them fairly during performance reviews. Hence, this form of relational trust is integral to ensuring that individual variable pay systems are perceived as fair, and contribute to employees’ pay satisfaction (Adams, 1963).

Thus far, our theoretical argument for the moderating role of trust in management applies equally to disabled and nondisabled employees. In short, both should benefit from relational trust under individual variable pay. However, there is reason to believe that trust in management may be particularly important in influencing the pay satisfaction of disabled employees who are paid based on their performance.

This reason is rooted in the cognitively demanding nature of making individual variable pay decisions. As previously discussed, managers hold negative stereotypes about disabled employees (Legnick-Hall et al., 2008; Smith et al., 2004) which may (un)intentionally downwardly bias their performance ratings. Moreover, supervisors tend to have lower expectations of disabled employees' future performance, and are reluctant in recommending them for promotions (Colella \& Varma, 1999; Ren et al., 2008). When managers are asked to make individual variable pay decisions, disabled individuals may fear that their manager relies on such stereotypes, and their decisions are not fair.

Indeed, stereotype threat theory and associated research on stigma has shown that individuals tend to mistrust in domains in which their group is stereotyped (Cohen, Steele, \& Ross, 1999; Crocker, Voelkl, Testa, \& Major, 1991; Steele \& Aronson, 1995). For example, an experimental study showed that participants who had a scar cosmetically (temporarily) applied to their face believed that an interaction partner behaved in an awkward and patronizing manner 
toward them - even when the participants' scars were removed without the participants' knowledge prior to the interaction (Kleck \& Strenta, 1980).

However, extensions of stereotype threat theory suggest that individuals who are stigmatized do not always feel mistreated in stereotype-relevant contexts. Instead, studies demonstrate that work-related factors can reduce the likelihood that a person believes that others will negatively stereotype him or her in stereotype-relevant contexts (Emerson \& Murphy, 2015; Purdie-Vaughns, Steele, Davies, Ditlmann, \& Crosby, 2008). From this, we predict that trust in management is a work-related factor that has the capacity to reduce disabled employees' beliefs that the performance management system, upon which variable pay is based, is biased. Specifically, we suggest that disabled individuals strongly value a trusting relationship with management because in a high trust situation, disabled employees believe that management avoids making stereotypical judgements of them. Compared with nondisabled employees, disabled individuals may require additional reassurance from management in order to feel that they are treated fairly. Indeed, disabled employees may believe that they need to work extra hard to develop a high quality relationship with their managers (Colella \& Varma, 2001).

In summary, we posit that disabled employees who have high trust in management will believe that pay decisions are made fairly under variable pay. Consistent with equity theory (Adams, 1963), this sense of justice will positively affect their pay satisfaction. In light of the above theory and evidence, we hypothesize:

Hypothesis 3: There is a three-way interaction among trust in management, disability status and individual variable pay such that when trust in management is high, the difference in pay satisfaction between disabled and nondisabled employees under variable pay is reduced. 
Disability policy and related HRM practices. The formal adoption of policies and practices that promote the fair treatment of disabled employees may demonstrate that the organization respects and provides equal opportunities to all (Schur, Kruse, \& Blanck, 2005; Stone \& Colella, 1996). Such policies and practices are capable of regulating employee behavior, defining what is appropriate and inappropriate (March, Schult, \& Zhou, 2000), fostering coordination and control, and reducing discrimination by ensuring that employees are treated uniformly (Sitkin \& Roth, 1993). In this sense, policies and practices may instil in employees the belief that they will be treated fairly, and in alignment with equity theory (Adams, 1963), pay satisfaction should increase because employees believe that they will be rewarded fairly.

At first blush, "practice" and "policy" may seem similar enough not to warrant further investigation. The field of HRM tends to use the terms interchangeably, however, as Becker and Gerhart (1996) noted, it is oftentimes important to distinguish between the two. Although decision makers may have the best of intentions when formulating and communicating policy regarding the fair treatment of disabled employees, policies (without practices) may be ineffectual, or even trigger negative consequences. Indeed, policy may raise the expectations of employees; when there are limited HRM practices that follow policy, it may create disappointment and consequently dissatisfaction. Erikson, von Schrader, Bruyere, and VanLooy (2014) found that only one quarter to one half of organizations that have disability-related fairness policies stated that they are effective, and Dibben, James, Cunningham, and Smythe (2002) suggested that disability-related policies are oftentimes designed to promote a positive corporate image, and not necessarily as a means to employ, engage, and retain disabled employees. In their analysis of workplaces in Britain, Hoque and Noon (2004) concluded that 
many equal opportunity policies are mere "empty shells." This research points to the need to investigate not only formal policies, but also HRM practices that are aligned with it.

HRM theory building has acknowledged that a gap can arise between espoused organizational policies relating to the management of people and the HRM practices that support them (Ezzamel, Lilley, Wilkinson \& Wilmott, 1996; Truss, 2001). Similarly, notions arising from the Michigan School of thought include that HRM practices need to be congruent with organizational strategy (Fombrun, Tichy, \& Devanna, 1984). As Gratton and Truss (2003) argued, "A key message is that the bridging from business goals to employee performance requires not only policies but also a determination to act, as seen through actual practice" (p. 75).

There are only two studies, to our knowledge, that have examined the impact of firm policy with and without corresponding HRM practice in relation to disability management. Cunningham, James and Dibben (2004) presented findings from four organisations, each of which had a seemingly robust policy for managing ill or disabled employees. They identified factors that inhibited the ability of line managers to comply with formal policies, many of which included HRM practices (e.g., training). The second study was based on qualitative data of new graduate disabled employees in the UK; William (2016, p. 349) found that when disabled employees worked for an organization that had a specialist equality and diversity HR manager, they were better able to secure reasonable adjustments than when they were absent, "even when formal policies existed." In fact, this research found that in organizations where there was a formal policy related to the provision of reasonable adjustment for disabled employees without corresponding HRM practices, adjustments were either difficult to achieve or failed altogether.

Based on the above theoretical arguments and evidence, we assert that institutional trust in the form of policy alone has little consequence for reducing the gap in pay satisfaction. 
Instead, it is only the combination of organization-wide policy and supportive HRM practices that will lead to a reduction in the pay satisfaction gap between disabled and nondisabled employees under variable pay.

Hypothesis 4: When a policy is combined with high level of HRM practices, the difference in pay satisfaction between disabled and nondisabled employees under variable pay is reduced. When a policy is combined with low level of HRM practices, the difference is increased.

\section{Method}

\section{Sample}

The data was drawn from the British 2011 Workplace Employment Relations Survey (WERS). WERS 2011 is the sixth survey in a series of nationally representative surveys of British workplaces, and was conducted between March 2011 and June 2012. The survey population was workplaces that employed 5 or more people. Employees were randomly sampled from the list provided by the workplace, which covered $90 \%$ of all employees in Britain. The response rates were $46 \%$ for the workplace interviews, and $54 \%$ for employee questionnaires.

We limited the sample to employees who provided valid answers to all the questions concerning this study and those who worked at least one year at the workplace so that we were able to ensure that they received individual variable pay, if they were entitled, and were familiar with the general management practices and behaviors. Doing so was particularly important given that trust in management and disability related polices feature in our model; trust develops over time as a function of the parties in a relationship having a history of interaction (Rousseau et al., 1998) and employees need time to be familiar with organizational policies. 
The final sample size was 11,210 employees in 1,806 workplaces. On average 6 employees per organization, with a maximum of 23 and minimum of 1 , are included in the final sample. Among the employees, 1,251 were disabled (11\%). This number is slightly higher than $8.8 \%$, the percentage of employed disabled people in Britain, as reported by the Department of Work and Pensions (2014).

\section{Measures}

Individual variable pay

Employees were asked: (1) "Do you receive payments based on your individual performance or output in your job here?” In our coding, 1 signifies that employees received individual variable pay during the past year; 0 signifies they did not receive individual variable pay in the past year.

Disability status

We created a dummy variable from the question, "Are your day-to-day activities limited because of a health problem or disability which has lasted, or is expected to last, at least 12 months?" Employees who answered 'Yes, limited a little" and 'Yes, limited a lot' to this question were coded as 1 , and those who answered 'No' were coded as 0 . We took this approach because there were only 170 disabled employees who indicated that they were "limited a lot." In order to ensure that we had adequate power for our analyses, and to reduce the chances for a Type 2 error, the two categories of "limited a little" and "limited a lot" were collapsed into one category. This question is similar to that used by Schur, Kruse, Blasi, and Blanck (2009), except that the time span of 6 months was extended to 12 months and "work, housework, or other major activities" was combined to "day-to-day activities."

\section{Trust in management}


We used a measure of trust in management as a proxy for relational trust. Employees were asked to indicate their agreement with six statements about their trust in management on a Likert-type scale of 1 (strongly disagree) to 5 (strongly agree). The six statements are: "Now thinking about the managers at this workplace, to what extent do you agree that managers...(1) can be relied upon to keep to their promises; (2) are sincere in attempting to understand employees' views; (3) deal with employees honestly; (4) understand about employees having to meet responsibilities outside work; (5) encourage people to develop their skills; and (6) treat employees fairly."

Results of an exploratory factor analysis showed that all six items belong to one latent variable - trust in management. All items have high factor loadings (above .74) and no items have high cross-loadings on other factors (the highest is .14). A scree test was performed by examining the graph of the eigenvalues. Oblique rotation showed that a one-factor model had the "cleanest" factor structure. Thus, trust in management was measured by taking the mean of the six responses. It has an alpha of 0.93 .

\section{Disability Policy}

Employers were asked if their organization had a formal written policy that explicitly mentioned equality of treatment or discrimination on the ground of disability. It is coded as 1 if the employer answered 'Yes' to this question and 0 if the answer was 'No.'

\section{Disability-Related HRM Practices}

Employers were asked the following five questions: do you (1) "monitor recruitment and selection by disability?"; (2) "review recruitment and selection by disability?"; (3) "monitor promotions by disability?" (4) “review promotion procedures by disability?" (5) "review relative pay rates by disability?"; We coded "Yes" as 1 and "No" as 0 . The "disability-related HRM 
practices" was an average index of five dichotomous variables with a reliability coefficient

(Cronbach alpha) of 0.84 .

Pay satisfaction

Employees were asked, "How satisfied are you with the amount of pay you receive?" on a scale that ranged from 1 (very dissatisfied) to 5 (very satisfied). Nagy (2002) showed that a single-item measure of pay satisfaction is highly correlated with a multiple-item measure of pay satisfaction, and concluded that a single item facet-measure of pay satisfaction is adequate.

\section{Control variables}

At the individual level, we controlled for age (9 categories; range from 16-17 to over 65), income (14 categories; range from less than $£ 60$ per week to $£ 1,5051$ or more per week), and tenure ( 5 categories; range from less than one year to 10 years or more). We treated these three variables as continuous because they have interval properties (i.e. the distance between the categories has a consistent meaning). In addition, according to Rhemtulla, Brosseau-Liard, and Savalei (2012), when categorical variables have at least 5 categories, the results will not differ if they are treated as categorical or continuous. At the individual level, we also controlled for gender, marital status, education, whether they receive base pay or only commissions, and number of work hours per week. We included these controls because past research indicates that these variables are related to pay satisfaction (e.g., Berkowitz, Fraser, Treasure, \& Cochran, 1987; Clark, 1996; Gazioglu \& Tansel, 2006). At the organization level, we controlled for organization size, union status, whether the organization had a job evaluation system, and whether the organizational representative stated that employees in the organization are paid based on merit. Prior research has shown that these too are related to satisfaction (e.g., Bender \& 
Sloane, 1998; Evans \& Ondrack, 1990; Gius, 2013; Green, 1973; Green \& Haywood, 2008;

London, 1976).

\section{Common method bias}

The WERS design contains elements suggested by Podsakoff, MacKenzie, Lee, and Podsakoff (2003; also see Chang, Van Witteloostuijn, \& Eden, 2010) for reducing the likelihood of common method bias. First, different scale points and anchors were used for different variables. Specifically, 'pay satisfaction' was measured on a 5-point Likert scale ranging from 'very satisfied' to 'very dissatisfied' and 'trust in management' was measured on a 5-point scale ranging from 'strongly agree' to 'strongly disagree'; disability status was measured on a different scale anchor (i.e., 'Yes' and 'No'); and individual variable pay was measured by asking the respondents to 'tick' the option if they received payments based on their individual performance or output. Second, there is a proximal separation of measures (i.e., the self-reported measures disability status, pay satisfaction, individual variable pay, and trust in management - belonged to different sections of the employee survey) which reduces the likelihood of common retrieval cues to answer subsequent questions. Third, respondents were assured that their responses were confidential, which reduces the possibility of social desirability bias. Fourth, data was collected from multiple sources (i.e., HRM practices were provided by the management questionnaire and trust in management was provided by employees). Finally, the tested regression models included multiple interaction effects, which reduces the potential for common method bias as respondents are unlikely to anticipate difficult-to-visualize interactions.

In addition to the above-mentioned strategies, we conducted Harman's single-factor test in STATA by simultaneously loading all items in factor analysis with no rotation to check whether the data may be contaminated by common method bias (Podsakoff et al., 2003). The 
results demonstrated that a single factor did not account for the majority of the covariance among the measures. Scholars suggest that if a single factor accounts for more than $50 \%$, common method bias is likely a concern (Podsakoff et al., 2003; Farndale, Van Ruiten, Kelliher, \& HopeHailey, 2011). Our results showed that it explained only $40 \%$ of the total variance. Thus, common method bias does not unduly influence the results of our analyses.

\section{Analytical strategy}

WERS is an employer-employee linked survey. Employees who work in the same workplace are likely to be similar, given their shared experiences of workplace practices and culture. Because the data are multilevel (employees nested in firms), all the hypotheses were tested using hierarchical linear modelling. We analyzed the data using Stata command XTREG with random effects estimator (thereby allowing both the intercepts and slopes to vary by organization), which is a command in Stata to deal with multi-level data.

\section{Results}

Table 1 presents the descriptive statistics and correlations among all of the variables. The number of hours that employees worked and income has a correlation of 0.61 and age and tenure has a correlation of 0.43 . These are the highest correlations among all variables, and they are in the expected direction. The correlation between disability status and income is small yet negative; this is consistent with previous research which shows that disabled employees earn less income than nondisabled employees (Gunderson \& Lee, 2016; Hallock et al., 2014; Longhi et al., 2012). Disability status is also positively related to age and tenure as well as negatively related to education. This indicates that disabled employees tend to be older, have more work experience and are less educated. These correlations are small, ranging from 0.04 to 0.14 . At the organization level, disability status is correlated with organization size and union status. 
Unionized and larger organizations have more disabled employees than nonunionized or smaller organizations. The correlations with gender suggest that women work fewer hours, earn less income, but are more satisfied with their pay. Individual variable pay was positively correlated with pay satisfaction. There is a nonsignificant relationship between disability status and individual variable pay; disabled employees are just as likely to be paid based on individual performance as nondisabled employees.

Table 2 presents descriptive information of the firm characteristics that are germane to the present study. Notably most organizations in our sample have a formal written policy on equal opportunities or managing diversity $(91 \%)$ but very few organizations have adopted related HRM practices. For example, only $10 \%$ of organizations review pay rates by disability and only $18 \%$ of organizations monitor promotions by disability.

\section{INSERT TABLES 1 AND 2 ABOUT HERE}

Table 3 presents the multi-level regression results. Model 1 presents the control variables only. In model 2 , the coefficient representing disability status is statistically significant and negative $(B=-.18, \mathrm{SE}=.04, p<.01)$. This shows that disabled employees are 0.18 points less satisfied with their pay than nondisabled employees. Therefore, hypothesis 1 is supported.

\section{INSERT TABLE 3 ABOUT HERE}

To test Hypothesis 2, we added individual variable pay and its product with disability status. As shown in model 3, the product variable is statistically significant and negative, and the 
change in the $R^{2}$ for the model is also significant. Figure 2 is the plot of the interaction effect and it demonstrates that disabled employees are less satisfied with their pay than nondisabled employees regardless of whether they received individual pay, but the gap is much larger under individual pay. The interaction coefficient $(B=-.37, \mathrm{SE}=.12, p<.01)$ in the regression suggests that, holding other predictors constants, the difference in pay satisfaction among disabled and nondisabled employees is 0.37 larger with individual variable pay than the difference without individual variable pay. Hypothesis 2 is therefore supported.

To test Hypothesis 3, we ran a three-way interaction and the results are shown in model 4; a comparison of the $R^{2}$ statistics show that model 4 was a significant improvement over model 3. The three-way interaction was significant $(B=-.21, \mathrm{SE}=.12, p<0.1)$. We plotted the three-way interaction effect of individual variable pay, disability status, and trust in management (i.e. one standard deviation above/below the mean) in Figure 3. The two-way interaction coefficient when trust in management is high is -.05. A Z-test shows that it is significantly different from the interaction coefficient in model $3(Z=13.09, p<0.01)$, which indicates that when trust in management is high, the difference in pay satisfaction between disabled and nondisabled employees under variable pay and without variable pay is reduced by 0.32 point, and this reduction is statistically significant. Thus Hypothesis 3 is supported.

To test Hypothesis 4, we ran a three-way interaction with observations that have a disability policy (disability policy $=1$ ). The results are shown in model 5; a comparison of the $R^{2}$ statistics show that model 5 was a significant improvement over model 3 . We plotted the interaction in Figure 4. The two-way interaction coefficient when the organization has a disability policy and HRM practice is high (-.24) indicates that when the organization has a disability policy and extensive disability-related HRM practices, the difference in pay 
satisfaction between disabled and nondisabled employees under variable pay decreased by 0.13 point. This supports Hypothesis 4. On the other hand, as our theoretical development suggested, the interaction coefficient when the organization has a disability policy and HRM practice is low is smaller than the one in model $3(B=-.51)$ : the difference in pay satisfaction between disabled and nondisabled employees under variable pay increased by 0.14 point. This shows that even when an organization has a disability policy in place, it alone fails to reduce the pay satisfaction and indeed backfires. The three way interaction has a coefficient of .28 and standard errors of .38 , which is not statistically significant.

\section{INSERT FIGURES 3 AND 4 ABOUT HERE}

\section{Discussion}

Our study responds to a call for more research on "understanding the differences in satisfaction among disabled employees" and "the identification of potential boundary conditions that moderate such job satisfaction differences, which can impact work outcomes"

(Theodorakopoulos \& Budhwar, 2015, p. 182). Our results show that disabled employees report lower levels of pay satisfaction, and this negative relationship was exacerbated under individual variable pay; the gap in pay satisfaction was larger when employees reported that they were paid based on individual performance. Although prior research has taken us a long way in understanding how HRM practices differentially impact disabled and nondisabled employees, our research contributes to both HRM and the workplace disability management literatures by showing that disabled employees are less satisfied with their pay, and even more so when they are paid based on individual performance. 
Had we stopped our analysis at this point, the results may have contributed to employers' reluctance to hire disabled people, especially in organizations where individual variable pay contributes to employees' total rewards. However, we also found that trust in management makes a difference. In fact, the results show that the gap in pay satisfaction between disabled and nondisabled employees under variable pay was reduced by approximately $68 \%$ when trust in management is high. Hence, employees with disabilities may relish the opportunity to be paid based on their individual performance, so long as they trust that management is fair and unbiased.

Our study also revealed that organizational policy combined with HRM practices decreased the gap in pay satisfaction by 35 percentage points. This finding is important for the field of HRM, as it shows that HRM practices that are aligned with a formal organizational policy has clear implications for the satisfaction of disabled employees. Conversely, the presence of a formal disability policy without corresponding HRM practices increased, rather than decreased the gap in pay satisfaction. Although organizations may have employees' best interests at heart in instituting formal policy aimed to ensure the fair treatment of disabled employees, our analyses show that they have the potential to backfire when they are uncoupled from HRM practices that support it.

The present study makes a significant contribution to the literature on the effects of trust in the workplace. The vast majority of theory and research on trust has been at the micro-level (Bachmann, 2011; Fuglsang \& Jagd, 2015) and has focused on employees' perceptions of trust in one's manager, co-workers, or organization (e.g., Alfes, Shantz \& Truss, 2012; Dirks \& Ferrin, 2002; Kong, Dirks \& Ferrin, 2014). Very few studies have examined firm-wide policies, or other forms of institutional based trust, and conditions under which actions designed to enhance 
institutional based trust may have unintended consequences (see Blatt, 2009; Bunderson \& Boumgarden, 2010; Malhotra \& Lumineau, 2011; Michael, 2006 for exceptions). This is the first study, to our knowledge, to examine the effects of micro and macro forms of trust, and one of very few to directly investigate policy versus practice in relation to disability management practices (Hoque \& Noon, 2002), and we therefore open the door for research on the effects of each individually and in concert.

We also contribute to the workplace disability literature which shows that disabled versus nondisabled employees have different needs in the context of other HRM practices, including career management (Kulkarni \& Gopakumar, 2014), socialization (Colella, 1994; Kulkarni \& Lengnick-Hall, 2011), performance management (Colella, DeNisi \& Varma, 1997), workplace accommodation (e.g., Schur et al., 2014) and recruitment and hiring (Lengnick-Hall et al., 2008; Smith et al., 2004). Our findings regarding relational and institutional trust also extend theory in this scholarly field. For instance, policies and practices feature in theory on the effective management of disabled employees as if the two are always mutually reinforcing (Stone \& Colella, 1996). Our results show that a formal disability policy increased the gap in pay satisfaction between disabled and nondisabled employees under variable pay in the absence of supportive HRM policies, and hence theory on the antecedents of disabled employees' reactions at work should note their differential effects.

Finally, our findings contribute to the HRM literature in at least two ways. First, we show the importance of aligning firm-wide policy with HRM practices. The finding that actions that aim to build institutional trust can backfire contributes to perceptions of HRM theory, and debates on how firm-level HRM policies may not always have their intended effects (Piening et al., 2014; Shantz, Alfes, Arevshatian, \& Bailey, 2016). Second, HRM scholars - especially those 
who study compensation in particular - may find our study of interest through a different interpretation of the results of the moderating effects. It is possible to position our findings such that disability status is a moderator of the relationship between individual variable pay and pay satisfaction. Our results (Model 3, Table 3) show that individual variable pay has a positive effect on the pay satisfaction of nondisabled employees, lending support to prior research which shows the beneficial effects of individual variable pay (e.g., Green \& Heywood, 2008; Heywood \& Wei, 2006; Williams, McDaniel, \& Nguyen, 2006). However, the effect is reversed for disabled employees; when paid based on performance, the relationship between individual variable pay and pay satisfaction is negative for those who are disabled. The present study is the first to reveal empirical evidence regarding the moderating role of disability status on the relationship between variable pay and pay satisfaction, and therefore responds to calls for research on factors that reduce the effectiveness of variable pay (e.g., Drago \& Garvey, 1998; Fernie \& Metcalf, 1999; Marsden, French, \& Kubo, 2001).

\section{Data Strengths and Limitations and Directions for Future Research}

The WERS provided us with a large sample of disabled people in the UK. As noted by Schur et al. (2005), the bulk of research on disability management is conducted in the laboratory and is assumed to generalize to the working population. They suggested that researchers should collect and analyse data from organizations to make accurate assessments about the responses of disabled people to work-related factors. Doing so, however, is difficult, as the number of disabled individuals in most organizations is relatively low. Our use of the 2011 WERS provided us with a sample of 1,251 disabled people, allowing us to make relatively confident conclusions with our data analysis. WERS has much to offer to researchers who focus on the work experiences of disabled people, as it can be used to assess the impact of specific HRM practices 
on employee outcomes. Notwithstanding the strengths of using the WERS, it comes with a number of limitations, which lead us to propose a number of directions for future research.

First, our empirical findings are based on cross-sectional data. Hence it is not possible to assert causal linkages amongst the variables. Moreover, the data is sourced from Britain, limiting the generalizability of our findings. For instance, the British government actively encourages employers to treat disabled people fairly (Prime Minister's Strategy Unit, 2005). Organizations located in countries that place little legal or institutional pressure on organizations to integrate disabled people may yield different insights (Konrad et al., 2016). Our findings may also generalize less well to other countries because reactions to individual variable pay differ by national culture (e.g., Chang, 2011). Moreover, it is beyond the scope of this paper to determine whether our results generalize to other "diverse" groups. Although disability, like race and gender, is a cultural construct that assigns traits to individuals on the basis of bodily individual differences, "the border between disabled and nondisabled is less permanent and more permeable than those between races and genders" (Couser, 2005, p. 97). Future research should therefore test our hypotheses using longitudinal designs in different national contexts, and with other social formations that emerge from interactions of disability, gender, race, class, and others.

Second, we could not parcel out the type of variable pay system that was used in each organization. There may be a difference in disabled employees' responses to variable pay depending on whether it is based on subjective measures (i.e. performance appraisals) versus objective measures (i.e. piece rate pay). The former arguably requires more trust between management and employees, in that performance measures must be seen as valid and reliable in the absence of verifiable data (Lawler, 2000). We also did not have detailed data on different facets of satisfaction with pay (i.e., satisfaction with pay level, pay structure, pay administration, 
benefits). Although research shows that these elements of pay satisfaction are highly correlated, they are different (Heneman \& Schwab, 1985). Future research should examine disabled employees' reactions to various permutations of variable pay based on the extent to which the pay system is based on verifiable data, against different facets of pay satisfaction. Future research should also examine perceptions of fairness or justice as mediators in our model, as this is central to our theorizing, and other psychological frameworks position it as central to explaining employees' pay satisfaction (e.g., Colquitt, Conlon, Wesson, Porter \& Ng, 2001; Crosby, 1976; Higgins, 1987).

Third, the WERS does not provide information on the amount of variable pay that is earned by employees. It might be that disabled employees who trust management do so because they receive higher variable pay. The receipt of variable pay may therefore mediate the moderated relationship to explain why disabled employees who are paid based on variable pay and who trust in management have higher levels of pay satisfaction. The WERS also does not contain information on the average pay level in the firm; their relative pay may have implications for how employees feel about their pay. Future research should investigate these possibilities.

A fourth limitation is that we were unable to test for the moderating effect of type of disability. Characteristics of a person's disability, including its origin, conceal-ability, disruptiveness, dangerousness, and aesthetic qualities are associated with different responses from the public (Stone \& Colella, 1996) and with different employee outcomes (Ren et al., 2008). For instance, it is possible that our results may be stronger for visible versus invisible disabilities. It is also possible that some individuals may indicate that they are disabled but do not believe that they are stereotyped because their disability is invisible. Hence, the rationale for our hypotheses may not hold for such individuals. Moreover, our theorizing assumes that all 
disabled employees respond similarly to variable pay, when there might be unique reactions based on personality traits (Cable \& Judge, 1994). Future research should therefore collect more data on the abovementioned qualities of a person's disability and examine their interactions with personality.

Another restriction we faced in using the WERS is that we are unable to link individual managers with individual employees. This may be important in this context, as managers' perceptions of an employee's disability (i.e. their belief of the "cause" of the disability) may influence managers' global perceptions of the disabled person. Instead, the WERS links the organization (not the manager) with employee respondents. We therefore suggest that future research examine how managers attribute disability at the dyadic level to determine whether this influences how decisions with regards to pay are made, and the reaction of disabled employees.

Limitations also arise due to the size of our sample. For instance, the empirical analyses explained a relatively small amount of variance, as evidenced by the $R^{2}$ statistics (from 0.03 to 0.17). This is a typical concern of studies that use large samples, which have higher amounts of unobserved heterogeneity, relative to smaller ones. For instance, research that examines HRM practices using large datasets report similar statistics (e.g., Booth, Park, \& Glomb, 2009 reported $R^{2}$ statistics from .05 to .22; Curran \& Walsworth, 2014 reported $R^{2}$ statistics from .06 to .20 ). However, as Combs (2010) explained, using larger samples brings benefits; for instance, using a larger sample enables us to obtain higher external validity, reduce the chances of committing a Type 2 error, and provide better estimates of the "real world" in the UK.

\section{Practical Implications}

This study sends a clear message to organizations interested in raising employee pay satisfaction - trust in management and a firm-wide disability policy coupled with aligned HRM 
practices - matters. In order to increase employees' trust in management, organizations can take a two-pronged approach. First, they should encourage management, via effective role modeling, training, and/or reward strategies, to be trustworthy. Second, managers need to be perceived as trustworthy, by cultivating relationships with employees that are characterized by relational trust. For example, in the context of designing and managing an individual variable pay system, managers can be trustworthy by ensuring that appropriate metrics are used to measure performance, abstaining from making decisions based on personal biases, setting achievable targets, and providing constructive feedback. Managers can develop trusting relationships with employees by incorporating a participative approach to individual variable pay and fully articulating to employees the process by which individual variable pay decisions are made. Although trust in management is important regardless of disability status, the results of our study highlight the need for management to take particular care in ensuring that disabled employees trust management. Managers who value integrating disabled people into the workplace and who are willing to mentor disabled employees should be selected and rewarded for their efforts (Stone \& Colella, 1996). Trust is likely to be especially important for disabled employees in the assignment of appropriate job duties and reasonable adjustments, and the trust that is cultivated between management and disabled employees may in fact constitute a different variant of trust. Managers must ensure that disabled people feel included in work related activities, especially given existing negative stereotypes and low performance expectations of disabled individuals (Ren et al., 2008; Stone \& Colella, 1996). To do so, management should partner with the HRM department to train managers and employees on disability issues, highlight the achievements of disabled people, and organize networking events where all employees share an opportunity to meet (Colella, 1994; Stone \& Colella, 1996). 
The results of our research also suggest that HRM professionals play an important role in creating an environment in which disabled employees feel that they are treated fairly in relation to pay. HRM professionals need to be aware that an organizational policy without aligned HRM practices may have unintended consequences. HRM practitioners oftentimes need to lobby their position to senior management and to justify costs for HRM practices. This research provides a clear reason why firms should invest in disability-related HRM practices, especially when a formal policy is present. Our results caution against the belief that the institution of a policy regarding the treatment of disabled employees is a cure-all remedy; instead, the role of the HRM department becomes pivotal in realizing the potential of the policy to influence the attitudes of disabled employees.

\section{Conclusion}

Employers are now, more than ever, focused on attracting and retaining a diverse workforce. Although skilled, talented, and motivated to work, disabled individuals are oftentimes overlooked for jobs. Organizations need to be equipped with understanding how to connect with and support disabled employees in order to capitalize on this underutilized labor pool. Although the present study confirmed that disabled people are less satisfied with their pay than their nondisabled counterparts and the difference is larger under individual variable pay, the data also revealed that trust in management decreased the gap in pay satisfaction. Additionally, our results showed that when disability-related policy and practices are both present, the gap in pay satisfaction decreased. The major take-away for HRM professionals is that they need not disband individual variable pay systems based on the belief that it is disadvantageous for disabled people so long as they ensure that there is high trust in management and that there are aligned HRM practices with the firm's policy on the treatment of disabled employees. 


\section{References}

Acker, J. (1990). Hierarchies, jobs, bodies: A theory of gendered organizations. Gender \& Society, 4(2), 139-158. doi: 10.1177/089124390004002002

Adams, J. S. (1963). Toward an understanding of inequity. The Journal of Abnormal and Social Psychology, 67(5), 422-436. doi: http://dx.doi.org/10.1037/h0040968

Aiden, H. \& McCarthy, A. (2014). Current attitudes towards disabled people. Scope About Disability. Retrieved from http://www.scope.org.uk/Scope/media/Images/Publication\%20Directory/Currentattitudes-towards-disabled-people.pdf

Alfes, K., Shantz, A., \& Truss, C. (2012). The link between perceived HRM practices, performance and well-being: The moderating effect of trust in the employer. Human Resource Management Journal, 22(4), 409-427. doi: 10.1111/1748-8583.12005

Ali, M., Schur, L., \& Blanck, P. (2011). What types of jobs do people with disabilities want? Journal of Occupational Rehabilitation, 21(2), 199-210. doi: 10.1007/s10926-010-9266-0

Ariss, A., Vassilopoulou, J., Özbilgin, M. F., \& Game, A. (2013). Understanding career experiences of skilled minority ethnic workers in France and Germany. International Journal of Human Resource Management, 24(6), 1236-1256. doi:

$10.1080 / 09585192.2012 .709190$

Bachmann, R. (2011). At the crossroads: Future directions in trust research. Journal of Trust Research, 1(2), 203-213. doi: 10.1080/21515581.2011.603513

Bê, A. (2012). Feminism and disability: A cartography of multiplicity. In N. Watson, A. Roulstone and C. Thomas (Eds.), Routledge Handbook of Disability Studies. London: Routledge, 363-375. 
Becker, B., \& Gerhart, B. (1996). The impact of human resource management on organizational performance: Progress and prospects. Academy of Management Journal, 39(4), 779-801. doi: $10.2307 / 256712$

Bender, K. A., \& Sloane, P. J. (1998). Job satisfaction, trade unions, and exit-voice revisited. Industrial \& Labor Relations Review, 51(2), 222-240. doi: $10.1177 / 001979399805100204$

Berkowitz, L., Fraser, C., Treasure, F. P., \& Cochran, S. (1987). Pay, equity, job gratifications, and comparisons in pay satisfaction. Journal of Applied Psychology, 72(4), 544. doi: $10.1037 / 0021-9010.72 .4 .544$

Blatt, R. (2009). Tough love: How communal schemas and contracting practices build relational capital in entrepreneurial teams. Academy of Management Review, 34(3), 533-551. doi: 10.5465/AMR.2009.40633298

Booth, J. E., Park, K. W. \& Glomb, T. M. (2009). Employer-supported volunteering benefits: Gift exchange among employers, employees, and volunteer organizations. Human Resource Management, 48(2), 227-249. doi: 10.1002/hrm.20277

Bowen, D. E., \& Ostroff, C. (2004). Understanding HRM-firm performance linkages: The role of the "strength" of the HRM system. Academy of Management Review, 29(2), 203-221. doi: 10.5465/AMR.2004.12736076

Bunderson, J. S., \& Boumgarden, P. (2010). Structure and learning in self-managed teams: Why "bureaucratic" teams can be better learners. Organization Science, 21(3), 609-624. doi: http://dx.doi.org/10.1287/orsc.1090.0483 
Cable, D. M., \& Judge, T. A. (1994). Pay preferences and job search decisions: A personorganization fit perspective. Personnel Psychology, 47(2), 317-348. doi: 10.1111/j.17446570.1994.tb01727.

Calas, M. B. \& Smircich, L. (1996). From 'the woman's point of view': Feminist approaches to organization studies. In S. R. Clegg \& C. Hardy’s, Studying Organization: Theory \& Method (pp. 212-252). Sage Publications.

Campbell, D. J., \& Lee, C. (1988). Self-appraisal in performance evaluation: Development versus evaluation. Academy of Management Review, 13(2), 302-314. doi:

10.5465/AMR.1988.4306896

Castilla, E. J., \& Benard, S. (2010). The paradox of meritocracy in organizations. Administrative Science Quarterly 55(4), 543-576. doi: 10.2189/asqu.2010.55.4.543

Chang, E. (2011). Motivational effects of pay for performance: A multilevel analysis of a Korean case. The International Journal of Human Resource Management, 22(18), 3929-3948. doi: $10.1080 / 09585192.2011 .561248$

Chang, S.-J., Van Witteloostuijn, A., \& Eden, L. (2010). From the editors: Common method variance in international business research. Journal of International Business Studies, 41(2), 178-184. doi: 10.1057/jibs.2009.88

Clark, A. E. (1996). Job satisfaction in Britain. British Journal of Industrial Relations, 34(2), 189-217. doi: 10.1111/j.1467-8543.1996.tb00648.x

Cohen, G. L., Steele, C. M., \& Ross, L. D. (1999). The mentor's dilemma: Providing critical feedback across the racial divide. Personality and Social Psychology Bulletin, 25(10), 1302-1318. doi: 10.1177/0146167299258011 
Couser, G. T. (2005). Disability as diversity: A difference with a difference. Ilha do Desterro: A Journal of English Language, Literatures in English and Cultural Studies, Florianópolis, 48, 095-113. ISSN 2175-8026.

Colella, A. (1994). Organizational socialization of employees with disabilities: Critical issues and implications for workplace interventions. Journal of Occupational Rehabilitation, 4(2), 87-106. doi: 10.1007/BF02110048

Colella, A. (1996). The organizational socialization of employees with disabilities: Theory and research. In G. Ferris. (Ed.), Research in personnel and human resources management (Vol. 14, pp. 351-417). Greenwich, CT: JAI Press.

Colella, A., DeNisi, A. S., \& Varma, A. (1997). Appraising the performance of employees with disabilities: A review and model. Human Resource Management Review, 7(1), 27-53. doi: 10.1016/S1053-4822(97)90004-8

Colella, A., \& Varma, A. (1999). Disability-job fit stereotypes and the evaluation of persons with disabilities at work. Journal of Occupational Rehabilitation, 9(2), 79-95. doi: 10.1023/A:1021362019948

Colella, A., \& Varma, A. (2001). The impact of subordinate disability on leader-member exchange relationships. Academy of Management Journal, 44(2), 304-315. doi: $10.2307 / 3069457$

Colquitt, J. A., Conlon, D. E., Wesson, M. J., Porter, C. O. L. H., Ng, K. Y. (2001). Justice at the millennium: A meta-analytic review of 25 years of organizational justice research. Journal of Applied Psychology, 86(3), 425-445. doi: http://dx.doi.org/10.1037/00219010.86 .3 .425 
Combs, J. G. (2010). Big samples and small effects: let's not trade relevance and rigor for power. Academy of Management Journal, 53(1), 9-13. doi: 10.5465/AMJ.2010.48036305

Cooke, L. F., \& Xiao, Y. (2014). Gender roles and organizational HR practices: The case of women's careers in accountancy and consultancy firms in China. Human Resource Management, 53(1), 23-44. doi: 10.1002/hrm.21566

Cox, T. H. and Blake, S. (1991). Managing cultural diversity: Implications for organizational competitiveness. Academy of Management Executive, 5(3), 45-56. Retrieved from http://www.jstor.org/stable/4165021

Crocker, J., Voelkl, K., Testa, M., \& Major, B. (1991). Social stigma: The affective consequences of attributional ambiguity. Journal of Personality and Social Psychology, 60(2), 218-228. doi: 10.1037/0022-3514.60.2.218

Crosby, F. (1976). A model of egoistical relative deprivation. Psychological Review, 83(2), 85113. doi: http://dx.doi.org/10.1037/0033-295X.83.2.85

Cunningham, I., James, P., \& Dibben, P. (2004). Bridging the gap between rhetoric and reality: Line managers and the protection of job security for ill workers in the modern workplace. British Journal of Management, 15(3), 273-290. doi:10.1111/j.1467-8551.2004.00419.x

Curran, B. \& Walsworth, S. (2014). Can you pay employees to innovate? Evidence from the Canadian private sector. Human Resource Management Journal, 24(3), 290-306. doi: $10.1111 / 1748-8583.12036$

Department for Business Innovation and Skills UK (2016). Retrieved from https://www.gov.uk/government/uploads/system/uploads/attachment_data/file/500760/BI S-16-35-non-financial-reporting-directive-consultation-February-2016.pdf 
Department of Work and Pensions (2014). Disability facts and figures. Retrieved from: https://www.gov.uk/government/publications/disability-facts-and-figures/disability-factsand-figures\#employment

DeNisi, A. S., \& Williams, K. J. (1988). Cognitive approaches to performance appraisal. In G. Ferris \& K. Rowland (Eds.), Research in personnel and human resources management (Vol. 6, pp. 109-155). Greenwich, CT: JAI Press.

Dibben, P., James, P., Cunningham, I., \& Smythe, D. (2002). Employers and employees with disabilities in the UK: An economically beneficial relationship? International Journal of Social Economics, 29(6), 453-467. doi: http://dx.doi.org/10.1108/03068290210426566

Dirks, K. T., \& Ferrin, D. L. (2002). Trust in leadership: Meta-analytic findings and implications for research and practice. Journal of Applied Psychology, 87(4), 611-628. doi: 10.1037/0021-9010.87.4.611

Drago, R., \& Garvey, G. T. (1998). Incentives for helping on the job: Theory and evidence. Journal of Labor Economics, 16(1), 1-25. doi: 10.1086/209880

Emerson, K., \& Murphy, M. (2015). A organization I can trust? Organizational lay theories moderate stereotype threat for women. Personality and Social Psychology Bulletin, 41(2), 295-307. doi: 10.1177/0146167214564969

Elvira, M. M., \& Graham, M. E. (2002). Not just a formality: Pay system formalization and sexrelated earnings effects. Organization Science, 13(6), 601-617. doi: http://dx.doi.org/10.1287/orsc.13.6.601.499

Equal Employment Opportunity Commission (2016). Retrieved from https://www.eeoc.gov/employers/eeo1survey/index.cfm 
Erikson, W. A., von Schrader, S., Bruyere, S. M., \& VanLooy, S. A. (2014). The employment environment: Employer perspectives, policies, and practices regarding the employment of persons with disabilities. Rehabilitation Counselling Bulletin, 57(4), 195-208. doi: $10.1177 / 0034355213509841$

Evans, M. G., \& Ondrack, D. A. (1990). The role of job outcomes and values in understanding the union's impact on job satisfaction: A replication. Human Relations, 43(5), 401-418. doi: $10.1177 / 001872679004300501$

European Commission (2014). Report on the implementation of the UN Convention on the Rights of Persons with Disabilities (CRPD) by the European Union. Retrieved from http://ec.europa.eu/justice/discrimination/files/swd_2014_182_en.pdf

Ezzamel, M., Lilley, S., Wilkinson, A., \& Willmott, H. (1996). Practices and practicalities in Human Resource Management. Human Resource Management Journal, 6(1), 63-80. doi:10.1111/j.17488583.1996.tb00397.x

Farndale, E., \& Kelliher, C. (2013). Implementing performance appraisal: Exploring the employee experience. Human Resource Management, 52(6), 879-897. doi: 10.1002/hrm.21575

Farndale, E., Van Ruiten, J., Kelliher, C., \& Hope-Hailey, V. (2011). The influence of perceived employee voice on organizational commitment: An exchange perspective. Human Resource Management, 50(1), 113-129. doi: 10.1002/hrm.20404

Fernie, S., \& Metcalf, D. (1999). It's not what you pay it's the way that you pay it and that's what gets results: Jockeys' pay and performance. Labor, 13(2), 385-411. doi: $10.1111 / 1467-9914.00100$ 
Fombrun, C.J., Tichy, M.M. and Devanna M. A. (1984) Strategic Human Resource Management, New York: John Wiley

Fuglsang, L., \& Jagd, S. (2015). Making sense of institutional trust in organizations: Bridging institutional context and trust. Organization, 22(1), 23-39. doi: $10.1177 / 1350508413496577$

Gazioglu, S., \& Tansel, A. (2006). Job satisfaction in Britain: Individual and job related factors. Applied Economics, 38(10), 1163-1171. doi: 10.1080/00036840500392987

Gius, M. (2013). The effects of merit pay on teacher job satisfaction. Applied Economics, 45(3133), 4443-4451. doi: 10.1080/00036846.2013.788783

Gonzales, J. A., \& DeNisi, A. S. (2009). Cross-level effects of demography and diversity climate on organizational attachment and firm effectiveness. Journal of Organizational Behavior, 30(1), 21-40. doi: 10.1002/job.498

Green, C.N. (1973). Causal connections among managers' merit pay, job satisfaction, and performance. Journal of Applied Psychology, 58(1), 95-100. doi: 10.1037/h0035417

Green, C., \& Heywood, J. S. (2008). Does performance pay increase job satisfaction? Economica, 75(300), 710-728. doi: 10.1111/j.1468-0335.2007.00649.x

Gratton, L., \& Truss, C. (2003). The three-dimensional people strategy: Putting human resources policies into action. The Academy of Management Executive, 17(3), 74-86. doi:10.5465/AME.2003.10954760

Guest, D. E. (1987). Human resource management and industrial relations. Journal of Management Studies, 24(5), 503-521. ISSN: 00222380 
Gunderson, M. \& Lee, B. (2016). Pay discrimination against persons with disabilities: Canadian evidence from PALS. The International Journal of Human Resource Management, 27(14), 1531-1549. doi: 10.1080/09585192.2015.1072106

Gupta, N. (1980). Performance-contingent rewards and satisfaction: An initial analysis. Human Relations, 33(11), 813-829. doi:10.1177/001872678003301104

Gupta, N., \& Jenkins, G. D. (1996). The politics of pay. Compensation \& Benefits Review, 28(2), 23-30. doi: 10.1177/088636879602800204

Gupta, N., \& Shaw, J. D. (1998). Let the evidence speak: Financial incentives are effective!! Compensation \& Benefits Review, 30(2), 26-32. doi: 10.1177/088636879803000205

Hallock, K. F., Jin, X., \& Barrington, L. (2014). Estimating pay gaps for workers with disabilities: Implications from broadening definitions and data sets. Rehabilitation Research, Policy, and Education, 28(4), 264-290. doi: 10.1891/2168-6653.28.4.264

Heneman III., H. G., \& Schwab, D. P. (1985). Pay satisfaction: Its multidimensional nature and measurement. International Journal of Psychology, 20(2), 129-141. doi: $10.1080 / 00207598508247727$

Hill, R. J. (2009). Incorporating queers: Blowback, backlash, and other forms of resistance to workplace diversity initiatives that support sexual minorities. Advances in Developing Human Resources, 11(1), 37-53. doi:10.1177/1523422308328128

Hewitt Salary Increase Survey (2009). Retrieved from: http://www.aon.com/attachments/thought-leadership/GettingItRight.pdf Heywood, J. S., \& Wei, X. (2006). Performance pay and job satisfaction. Journal of Industrial Relations, 48(4), 523-540. doi: 10.1177/0022185606066143 
Higgins, E. T. (1987). Self-discrepancy: A theory relating self and affect, Psychological Review, 94(3), 319-340. doi: http://dx.doi.org/10.1037/0033-295X.94.3.319

Hoque, K., \& Noon, M. (2004). Equal opportunities policy and practice in Britain: Evaluating the 'empty shell hypothesis'. Work, Employment, and Society, 18(3), 481-506. doi: $10.1177 / 0950017004045547$

Jones, B. J., Gallagher, B. J., Kelley, J. M., \& Massari, L. O. (1991). A survey of Fortune 500 corporate policies concerning the psychiatrically handicapped. The Journal of Rehabilitation, 57(4), 31-35. ISSN: 0022-4154

Kanter, R. M. (1977). Men and Women of the Corporation. New York: Basic Books.

Kehoe, R. R. \& Wright, P. M. (2002). The impact of high performance human resource practices on employees' attitudes and behaviors. Journal of Management, 39, 366-391. doi: $10.1177 / 0149206310365901$

Kleck, R. E., \& Strenta, A. (1980). Perceptions of the impact of negatively valued physical characteristics on social interaction. Journal of Personality and Social Psychology, 39(5), 861-873. doi: 10.1037/0022-3514.39.5.861

Kong, D. T., Dirks, K. T., \& Ferrin, D. L. (2014). Interpersonal trust within negotiations: Metaanalytic evidence, critical contingencies, and directions for future research. Academy of Management Journal, 57(5), 1235-1255. doi: 10.5465/amj.2012.0461

Konrad, A. M., Yang, Y. \& Maurer, C. C. (2016). Antecedents and outcomes of diversity and equality management systems: An integrated institutional agency and strategic human resource management approach. Human Resource Management, 55(1), 83-107. doi: 10.1002/hrm.21713 
Kooij, D. T., Jansen, P. G., Dikkers, J. S., \& De Lange, A. H. (2010). The influence of age on the associations between HR practices and both affective commitment and job satisfaction: A meta-analysis. Journal of Organizational Behavior, 31(8), 1111-1136. doi: 10.1002/job.666

Kulkarni, M., \& Gopakumar, K. V. (2014). Career management strategies of people with disabilities. Human Resource Management, 53(3), 445-466. doi: 10.1002/hrm.21570

Kulkarni, M., \& Lengnick-Hall, M. L. (2011). Socialization of people with disabilities in the workplace. Human Resource Management, 50(4), 521-540. doi: 10.1002/hrm.20436

Lawler III, E.E. (2000). Rewarding excellence: Pay strategies for the new economy. San Francisco, CA: Jossey-Bass.

Liao, H., Toya, K., Lepak, D. P., \& Hong, Y. 2009. Do they see eye to eye? Management and employee perspectives of high performance work systems and influence processes on service quality. Journal of Applied Psychology, 94(2), 371-391. doi:

http://dx.doi.org/10.1037/a0013504

Lengnick-Hall, M. L., Gaunt, P. M., \& Kulkarni, M. (2008). Overlooked and underutilized: People with disabilities are an untapped human resource. Human Resource Management, 47(2), 255-273. doi: 10.1002/hrm.20211

London, M. (1976). Employee perceptions of the job reclassification process. Personnel Psychology, 29(1), 67-77. doi: 10.1111/j.1744-6570.1976.tb00403.x

Longhi, S., Nicoletti, C., \& Platt, L. (2012). Interpreting wage gaps of disabled men: The roles of productivity and of discrimination. Southern Economic Journal, 78(3), 931-953. ISSN: 00384038 
Malhotra, D., \& Lumineau, F. (2011). Trust and collaboration in the aftermath of conflict: The effects of contract structure. Academy of Management Journal, 54(5), 981-998. doi: 10.5465/amj.2009.0683

March, J. G., Schult, M. \& Zhou, X. (2000). The dynamics of rules. Stanford University Press: Stanford California.

Marsden, D., French, S., \& Kubo, K. (2001). Does performance pay de-motivate, and does it matter? Discussion Paper no. 503, London School of Economics Centre for Economic Performance.

McAfee, J. K. \& McNaughton, D. (1997). Transitional outcomes: Job satisfaction of workers with disabilities - Part 2. Journal of Vocational Rehabilitation, 8(3), 243-51. doi: 10.3233/JVR-1997-8305

Miceli, M. P., \& Lane, M. C. (1991). Antecedents of pay satisfaction: A review and extension. In K. Rowland \& J. Ferris (Eds.), Research in personnel and human resources management (Vol. 9, pp. 235-309). Greenwich, CT: JAI Press.

Michael, M. L. (2006). Business ethics: The law of rules. Business Ethics Quarterly, 16(4), 475504. doi: http://dx.doi.org/10.5840/beq200616445

Morris, J. (1991). Pride against Prejudice. The Women's Press: London.

Nagy, M. S. (2010). Using a single-item approach to measure facet job satisfaction. Journal of Occupational and Organizational Psychology, 75(1), 77-86. doi: $10.1348 / 096317902167658$

Piening, E. P., Baluch, A. M., \& Ridder, H. G. (2014). Mind the intended-implemented gap: Understanding employees’ perceptions of HRM. Human Resource Management, 53(4), 545-567. doi: 10.1002/hrm.21605 
Podsakoff, P. M., MacKenzie, S. B., Lee, J.-Y., \& Podsakoff, N. P. (2003). Common method biases in behavioral research: A critical review of the literature and recommended remedies. Journal of Applied Psychology, 88(5), 879-903. doi: 10.1037/00219010.88 .5 .879

Prime Minister's Strategy Unit. (2005). Improving the life chances of disabled people. London, UK: The Cabinet Office Strategy Unit.

Purdie-Vaughns, V., Steele, C. M., Davies, P. G., Ditlmann, R., \& Crosby, J. R. (2008). Social identity contingencies: How diversity cues signal threat or safety for African Americans in mainstream institutions. Journal of Personality and Social Psychology, 94(4), 615-630. doi: 10.1037/0022-3514.94.4.615

Ren, L. R., Paetzold, R. L., \& Colella, A. (2008). A meta-analysis of experimental studies on the effects of disability on human resource judgments. Human Resource Management Review, 18(3), 191-203. doi: 10.1016/j.hrmr.2008.07.001

Rhemtulla, M., Brosseau-Liard, P. E., \& Savalei, V. (2012). When can categorical variables be treated as continuous? A comparison of robust continuous and categorical SEM estimation methods under suboptimal conditions. Psychological Methods, 17(3), 354373. doi: $10.1037 / \mathrm{a} 0029315$

Rousseau, D. M., Sitkin, S. B., Burt, R. S., \& Camerer, C. (1998). Not so different after all: A cross-discipline view of trust. Academy of Management Review, 23(3), 393-404._doi: 10.5465/AMR.1998.926617

Rynes, S. L., Gerhart, B., \& Parks, L. (2005). Performance evaluation and pay for performance. Annual Review of Psychology, 56, 571-600. doi:

10.1146/annurev.psych.56.091103.070254 
Schur, L., Kruse, D., \& Blanck, P. (2005). Corporate culture and the employment of persons with disabilities. Behavioral Sciences \& the Law, 23(1), 3-20. doi:10.1002/bsl.624

Schur, L., Kruse, D., Blasi, J., \& Blanck, P. (2009). Is disability disabling in all workplaces? Workplace disparities and corporate culture. Industrial Relations, 48(3), 381-410. doi: 10.1111/j.1468-232X.2009.00565.x

Schur, L., Nishii, L., Adya, M., Kruse, D., Bruyere, S. M., \& Blanck, P. (2014). Accommodating employees with and without disabilities. Human Resource Management, 53(4), 593-621. doi: $10.1002 / \mathrm{hrm} .21607$

Shantz, A., Alfes, K., \& Arevshatian, L., \& Bailey, C. (2016). The effect of HRM attributions on emotional exhaustion and the mediating roles of job involvement and work overload. Human Resource Management Journal, 26(2), 172-191. doi: 10.1111/1748-8583.12096

Sitkin, S. B., \& Roth, N. L. (1993). Explaining the limited effectiveness of legalistic "remedies" for trust/distrust. Organization Science, 4(3), 367-392. doi: http://dx.doi.org/10.1287/orsc.4.3.367

Smith, K., Webber, L., Graffam, J., \& Wilson, C. (2004). Employer satisfaction with employees with a disability: Comparisons with other employees. Journal of Vocational Rehabilitation, 21(2), 61-69. ISSN: 1052-2263

Staniland, L. (2011) Public perceptions of disabled people: Evidence from the British Social Attitudes Survey 2009. Office for Disability Issues, HM Government.

Steele, C. M., \& Aronson, J. (1995). Stereotype threat and the intellectual test performance of African Americans. Journal of Personality \& Social Psychology, 69(5), 797-811. doi: http://dx.doi.org/10.1037/0022-3514.69.5.797 
Stone, D. L., \& Colella, A. (1996). A model of factors affecting the treatment of disabled individuals in organizations. Academy of Management Review, 21(2), 352-401._doi: 10.5465/AMR.1996.9605060216

Subeliani, D., \& Tsogas, G. (2005). Managing diversity in the Netherlands: A case study of Rabobank. International Journal of Human Resource Management, 16(5), 831-851. doi: $10.1080 / 09585190500083392$

Theodorakopoulos, N. \& Budhwar, P. (2015). Guest editors' introduction: Diversity and inclusion in different work settings: Emerging patterns, challenges, and research agenda. Human Resource Management, 54(2), 177-197. doi: 10.1002/hrm.21715

Truss, C. (2001). Complexities and controversies in linking HRM with organizational outcomes. Journal of Management Studies, 38(8), 1121-1149. doi:10.1111/1467-6486.00275

van Dijke, M., de Cremer, D., Bos, A. E., \& Schefferlie, P. (2009). Procedural and interpersonal fairness moderate the relationship between outcome fairness and acceptance of merit pay. European Journal of Work and Organizational Psychology, 18(1), 8-28. _doi: $10.1080 / 13594320701856699$

William, L. (2016). The implementation of equality legislation: The case of disabled graduates and reasonable adjustments. Industrial Relations Journal, 47(4), 341-359. doi: 10.1111/irj.12143

Williams, M. L., McDaniel, M. A., \& Nguyen, N. T. (2006). A meta-analysis of the antecedents and consequences of pay level satisfaction. Journal of Applied Psychology, 91(2), 392413. doi: 10.1037/0021-9010.91.2.392 
Witte, R. H., Philips, L., \& Kakela, M. (1998). Job satisfaction of college graduates with learning disabilities. Journal of Learning Disabilities, 31(3), 259-265. doi: $10.1177 / 002221949803100305$

Woodhams, C., Lupton, B., Perkins, G. \& Cowling, M. (2015). Multiple disadvantage and wage growth: The effect of merit pay on pay gaps. Human Resource Management, 54(2) 283301. doi: 10.1002/hrm.21692

Zucker, L. G. (1986). Production of trust: Institutional sources of economic structure. Research in Organizational Behavior, 8, 53-111. ISSN: 0191-3085 


\section{Tables and Figures}

Table 1. Descriptive Statistics and Intercorrelations

\begin{tabular}{|c|c|c|c|c|c|c|c|c|c|c|c|c|c|c|c|c|c|c|}
\hline Variable & Mean & S.D. & 1 & 2 & 3 & 4 & 5 & 6 & 7 & 8 & $s$ & 10 & 11 & 12 & 13 & 14 & 15 & 16 \\
\hline 1. Pay satisfaction & 2.82 & 1.12 & & & & & & & & & & & & & & & & \\
\hline 2. Disability ${ }^{\mathrm{a}}$ & .11 & .31 & $-.06 *$ & & & & & & & & & & & & & & & \\
\hline $\begin{array}{l}\text { 3. Individual variable } \\
\text { pay }^{\mathrm{a}}\end{array}$ & .08 & .27 & .02 & -.01 & & & & & & & & & & & & & & \\
\hline $\begin{array}{l}\text { 4. Trust in } \\
\text { management }\end{array}$ & 3.40 & .93 & $.41 *$ & $-.10^{*}$ & .02 & & & & & & & & & & & & & \\
\hline 5. Disability policy ${ }^{a}$ & .81 & .38 & $-.07 *$ & .02 & .01 & $-.10^{*}$ & & & & & & & & & & & & \\
\hline 6. Gender ${ }^{b}$ & .58 & .49 & $.08 *$ & .02 & -.01 & $.14 *$ & .01 & & & & & & & & & & & \\
\hline 7. Age & 5.72 & 1.46 & -.03 & $.14 *$ & $-.06^{*}$ & -.02 & -.01 & -.03 & & & & & & & & & & \\
\hline 8. Income & 6.98 & 2.52 & -.01 & -.01 & $.05 *$ & $-.13 *$ & $.07 *$ & $-.28 *$ & .03 & & & & & & & & & \\
\hline $\begin{array}{l}\text { 9. Work hours per } \\
\text { week }\end{array}$ & 33.34 & 12.49 & $-.11 *$ & -.01 & .02 & $-.13 *$ & -.01 & $-.31^{*}$ & $-.03 *$ & $.61^{*}$ & & & & & & & & \\
\hline 10. Job tenure & 3.71 & 1.01 & -.01 & $.07 *$ & -.02 & $-.11 *$ & .01 & .02 & $.43^{*}$ & $.13^{*}$ & .01 & & & & & & & \\
\hline 11. Marital status ${ }^{\mathrm{c}}$ & .67 & .47 & .03 & .01 & -.03 & -.01 & -.01 & -.01 & $.25^{*}$ & $.08 *$ & .01 & $.13^{*}$ & & & & & & \\
\hline 12. Education & .19 & .39 & -.03 & $-.04 *$ & .02 & .02 & .03 & $.05^{*}$ & $-.15 *$ & $.12^{*}$ & -.01 & $-.14^{*}$ & -.01 & & & & & \\
\hline 13. Base pay ${ }^{a}$ & .93 & .26 & .01 & 0.02 & $-0.28 *$ & .01 & .01 & .02 & .03 & $.07 *$ & $-.05^{*}$ & $.03 *$ & .02 & $.06^{*}$ & & & & \\
\hline 14.Union status ${ }^{\mathrm{a}}$ & 5.21 & 17.79 & -.02 & $0.04 *$ & $-0.04 *$ & $-.05^{*}$ & $.06^{*}$ & .01 & $.06^{*}$ & $.04 *$ & -.01 & $.07 *$ & $.04 *$ & .01 & .03 & & & \\
\hline 15. Organization size & 4.54 & 1.74 & -.03 & $0.05^{*}$ & 0.02 & $-.18^{*}$ & $.36^{*}$ & $-.05^{*}$ & $.06^{*}$ & $.19 *$ & .03 & $.11^{*}$ & .02 & $.05^{*}$ & $.04^{*}$ & $.13 *$ & & \\
\hline 16. Job evaluation ${ }^{\mathrm{a}}$ & .35 & .48 & -.01 & 0.02 & -0.01 & -.01 & $.21 *$ & $.09 *$ & $.04 *$ & $.09 *$ & $-.08 *$ & $.07 *$ & .01 & $.09 *$ & $.05^{* *}$ & $.13 *$ & $.31 *$ & \\
\hline $\begin{array}{l}\text { 17. Diversity-related } \\
\text { HRM practices }\end{array}$ & 0.25 & 0.32 & -.01 & .04 & $-.04 *$ & $-.05^{*}$ & $.27 *$ & $.08 *$ & $.07 *$ & $.10^{*}$ & $-.06^{*}$ & $.04 *$ & .03 & $.08^{*}$ & $.05^{*}$ & $.15^{*}$ & $.38^{*}$ & $.33^{*}$ \\
\hline
\end{tabular}


18. Merit pay .24
.43
$-.04 * \quad .01$
$.06 *$
$-.04$

.02

.04

$-.04 *$

$\begin{array}{llll}.06 * & -.02 & -.03 & -.01\end{array}$

$.07 * \quad .05 * \quad-.03$

$.15^{*}$

Source: British 2011 Workplace Employment Relations Survey (WERS). The sample means and standard errors are fully weighted to account for the complex survey design.

Notes: ${ }^{\mathrm{a}} 1=\mathrm{yes}, 0=$ no; ${ }^{\mathrm{b}} 1=$ female, $0=$ male; ${ }^{\mathrm{c}} 1=$ married, $0=$ single; ${ }^{*} p<.01$ 
Table 2. Descriptive Statistics on Firm Characteristics

\begin{tabular}{|c|c|c|}
\hline Characteristics & Mean & Std. Dev \\
\hline Company size ( log of total number of employees) & 4.38 & 1.72 \\
\hline Union status (percentage of employees who are members of a trade union) & 6.43 & 19.40 \\
\hline Job evaluation system $((1=$ Yes, $0=\mathrm{No})$ & .42 & .49 \\
\hline Merit pay system $(1=$ Yes, $0=$ No) & .25 & .44 \\
\hline Diversity-related HRM practices & .25 & .32 \\
\hline Have a formal written policy on equal opportunities or managing diversity $(1=$ Yes, $0=$ No) & .91 & .29 \\
\hline Have a formal policy that explicitly mentions disability $(1=$ Yes, $0=$ No) & .80 & .40 \\
\hline Monitor recruitment and selection by disability $(1=\mathrm{Yes}, 0=\mathrm{No})$ & .42 & .49 \\
\hline Review recruitment and selection by disability $(1=$ Yes, $0=$ No $)$ & .33 & .47 \\
\hline Monitor promotions by disability $(1=\mathrm{Yes}, 0=\mathrm{No})$ & .18 & .38 \\
\hline Review promotion procedures by disability $(1=$ Yes, $0=$ No $)$ & .19 & .39 \\
\hline Reviews relative pay rates by disability $(1=$ Yes, $0=$ No $)$ & .10 & .30 \\
\hline Total number of organizations & \multicolumn{2}{|c|}{1806} \\
\hline
\end{tabular}


Table 3. Multilevel Regression analyses of individual variable pay, disability status, and trust in management on pay satisfaction (robust standard errors in parentheses)

\begin{tabular}{|c|c|c|c|c|c|}
\hline Independent Variables & Model 1 & Model 2 & Model 3 & Model 4 & Model $5^{e}$ \\
\hline Gender $^{\mathrm{a}}$ & $\begin{array}{c}.12 * * * \\
(.03)\end{array}$ & $\begin{array}{c}.12 * * * \\
(.03)\end{array}$ & $\begin{array}{c}.12 * * * \\
(.03)\end{array}$ & $\begin{array}{l}.05 * * \\
(.02)\end{array}$ & $\begin{array}{c}.12 * * * \\
(.03)\end{array}$ \\
\hline Age & $\begin{array}{c}.01 \\
(.01)\end{array}$ & $\begin{array}{c}.01 \\
(.01)\end{array}$ & $\begin{array}{c}.01 \\
(.01)\end{array}$ & $\begin{array}{l}-.01 \\
(.01)\end{array}$ & $\begin{array}{c}.01 \\
(.01)\end{array}$ \\
\hline Income & $\begin{array}{c}.06 * * * \\
(.01)\end{array}$ & $\begin{array}{c}.06 * * * \\
(.01)\end{array}$ & $\begin{array}{c}.06 * * * \\
(.01)\end{array}$ & $\begin{array}{c}.06 * * * \\
(.01)\end{array}$ & $\begin{array}{c}.06 * * * \\
(.01)\end{array}$ \\
\hline Work hours per week & $\begin{array}{c}-.02 * * * \\
(.00)\end{array}$ & $\begin{array}{c}-.02 * * * \\
(.00)\end{array}$ & $\begin{array}{c}-.02 * * * \\
(.00)\end{array}$ & $\begin{array}{c}-.01 * * * \\
(.00)\end{array}$ & $\begin{array}{c}-.02 * * * \\
(.00)\end{array}$ \\
\hline Job tenure & $\begin{array}{l}-.02 * \\
(.01)\end{array}$ & $\begin{array}{l}-.02 * \\
(.01)\end{array}$ & $\begin{array}{l}-.02 * \\
(.01)\end{array}$ & $\begin{array}{l}-.01 * \\
(.01)\end{array}$ & $\begin{array}{l}-.02 * \\
(.01)\end{array}$ \\
\hline Marriage status ${ }^{b}$ & $\begin{array}{c}.02 \\
(.03)\end{array}$ & $\begin{array}{c}.01 \\
(.02)\end{array}$ & $\begin{array}{c}.02 \\
(.02)\end{array}$ & $\begin{array}{c}.01 \\
(.03)\end{array}$ & $\begin{array}{c}.02 \\
(.02)\end{array}$ \\
\hline Education $^{c}$ & $\begin{array}{c}-.09 * * \\
(.03)\end{array}$ & $\begin{array}{c}-.09 * * \\
(.03)\end{array}$ & $\begin{array}{c}-.08 * * \\
(.03)\end{array}$ & $\begin{array}{l}-.10 * \\
(.03)\end{array}$ & $\begin{array}{c}-.07 * * * \\
(.03)\end{array}$ \\
\hline Base pay ${ }^{\mathrm{d}}$ & $\begin{array}{c}.01 \\
(.05)\end{array}$ & $\begin{array}{c}.01 \\
(.05)\end{array}$ & $\begin{array}{c}.03 \\
(.05)\end{array}$ & $\begin{array}{c}.01 \\
(.04)\end{array}$ & $\begin{array}{c}.03 \\
(.05)\end{array}$ \\
\hline Union status $^{\mathrm{d}}$ & $\begin{array}{c}-.01 * * \\
(.00)\end{array}$ & $\begin{array}{c}-.01 * * \\
(.00)\end{array}$ & $\begin{array}{l}-.01 * \\
(.00)\end{array}$ & $\begin{array}{l}-.01 \\
(.01)\end{array}$ & $\begin{array}{l}-.01 \\
(.00)\end{array}$ \\
\hline Organization size & $\begin{array}{l}-.01 \\
(.01)\end{array}$ & $\begin{array}{l}-.01 \\
(.01)\end{array}$ & $\begin{array}{l}-.01 \\
(.01)\end{array}$ & $\begin{array}{c}.03 * * * \\
(.01)\end{array}$ & $\begin{array}{l}-.01 \\
(.01)\end{array}$ \\
\hline 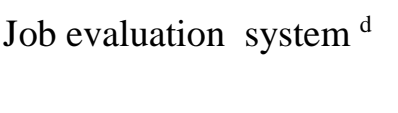 & $\begin{array}{l}-.04 \\
(.03)\end{array}$ & $\begin{array}{l}-.04 \\
(.03)\end{array}$ & $\begin{array}{l}-.04 \\
(.03)\end{array}$ & $\begin{array}{l}-.05 * \\
(.02)\end{array}$ & $\begin{array}{l}-.02 \\
(.03)\end{array}$ \\
\hline Firm level merit pay & $\begin{array}{l}-.04 \\
(.03)\end{array}$ & $\begin{array}{l}-.04 \\
(.03)\end{array}$ & $\begin{array}{l}-.04 \\
(.03)\end{array}$ & $\begin{array}{l}-.03 \\
(.03)\end{array}$ & $\begin{array}{l}-.06 * \\
(.03)\end{array}$ \\
\hline Disability $^{\mathrm{d}}$ & & $\begin{array}{c}-.18 * * * \\
(.04)\end{array}$ & $\begin{array}{c}-.15 * * * \\
(.04)\end{array}$ & $\begin{array}{l}-.03 \\
(.11)\end{array}$ & $\begin{array}{c}-.17 * * * \\
(.05)\end{array}$ \\
\hline Individual variable pay ${ }^{\mathrm{d}}$ & & & $\begin{array}{c}.14 * * * \\
(.05)\end{array}$ & $\begin{array}{c}.06 \\
(.16)\end{array}$ & $\begin{array}{l}.12 * \\
(.07)\end{array}$ \\
\hline
\end{tabular}


Disability X

Individual variable pay

Trust in management

Disability X

Trust in management

Individual variable pay $\mathrm{X}$

Trust in management

Disability X

Individual variable pay $\mathrm{X}$

Trust in management

Disability-related HRM

practices

Disability X

Disability-related HRM

practices

Individual variable pay $\mathrm{X}$

Disability-related HRM

practices

Disability X

Individual variable pay $\mathrm{X}$

Disability-related

HRM practices
$-.37 * * *$

(.12)

.42

(.38)

$-.56 * * *$

(.17)

$.48 * * *$

.01

$-.21 *$

$-.03$

(.05)

\begin{tabular}{lccccc} 
Constant & $3.01 * * *$ & $3.00 * * *$ & $2.96 * * *$ & $1.08 * * *$ & $2.82 * * *$ \\
& $(.09)$ & $(.09)$ & $(.08)$ & $(.09)$ & $(.09)$ \\
Overall $R^{2}$ & .02 & .03 & .03 & .17 & .03 \\
$\Delta R^{2}$ & $.02 * * *$ & $.01 * * *$ & $.01 * * *$ & $.14 * * *$ & $\mathrm{n} / \mathrm{a}$ \\
\hline
\end{tabular}

Notes: ${ }^{\mathrm{a}} 1=$ female, $0=$ male $;{ }^{\mathrm{b}} 1=$ married, $0=\operatorname{single} ;{ }^{\mathrm{c}} 1=$ first degree or higher, $0=$ without first degree; ${ }^{\mathrm{d}} 1=\mathrm{yes}, 0=$ no $* p<.10, * * p<.05, * * * p<.01$

Employees $\mathrm{n}=11,210$; workplaces $\mathrm{n}=1,806$

${ }^{\mathrm{e}}$ Employees n= 9,453; workplaces $\mathrm{n}=1,548$ 
Figure 1. Theoretical model

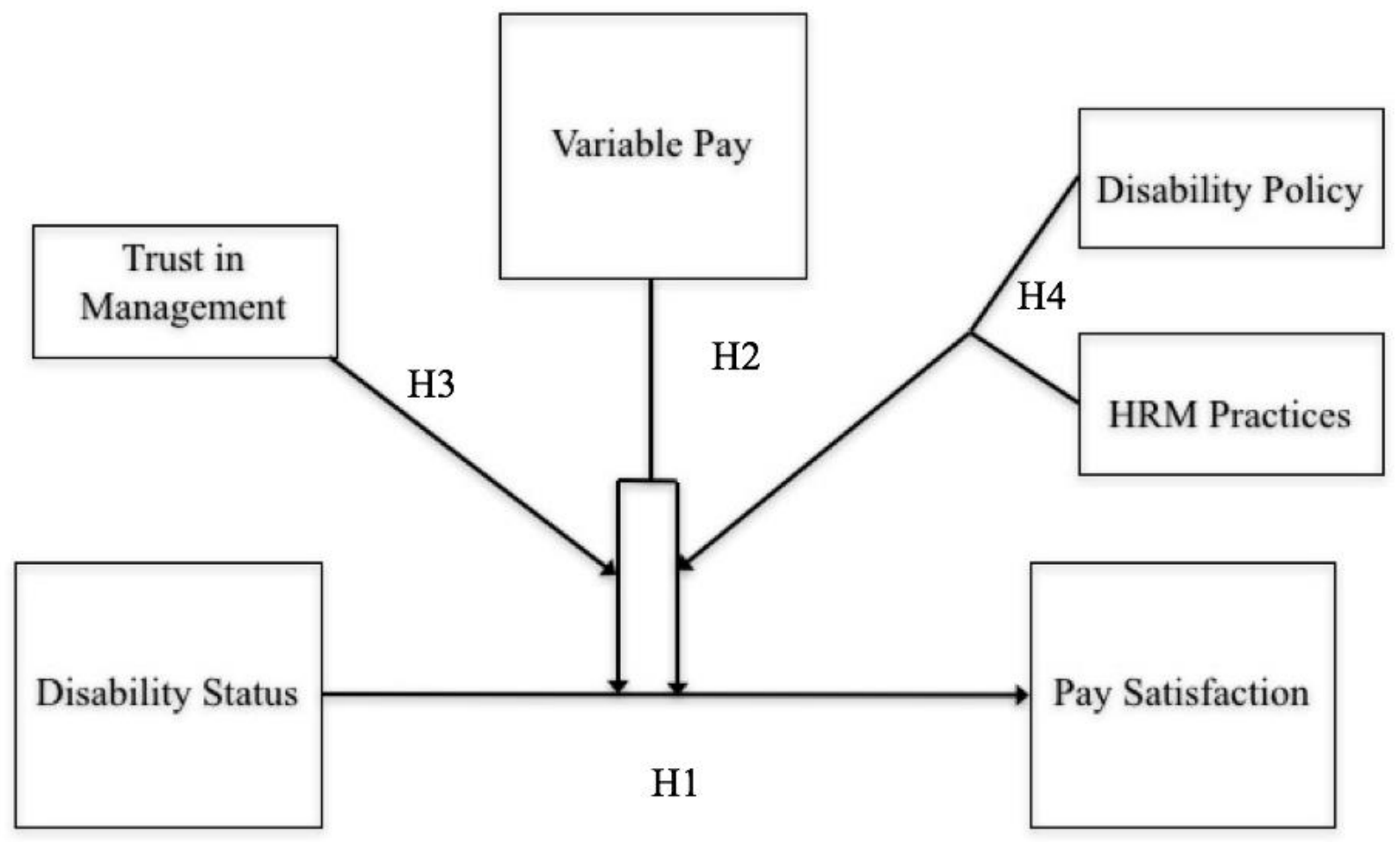


Figure 2. The two-way interaction of individual variable pay and disability status on pay satisfaction

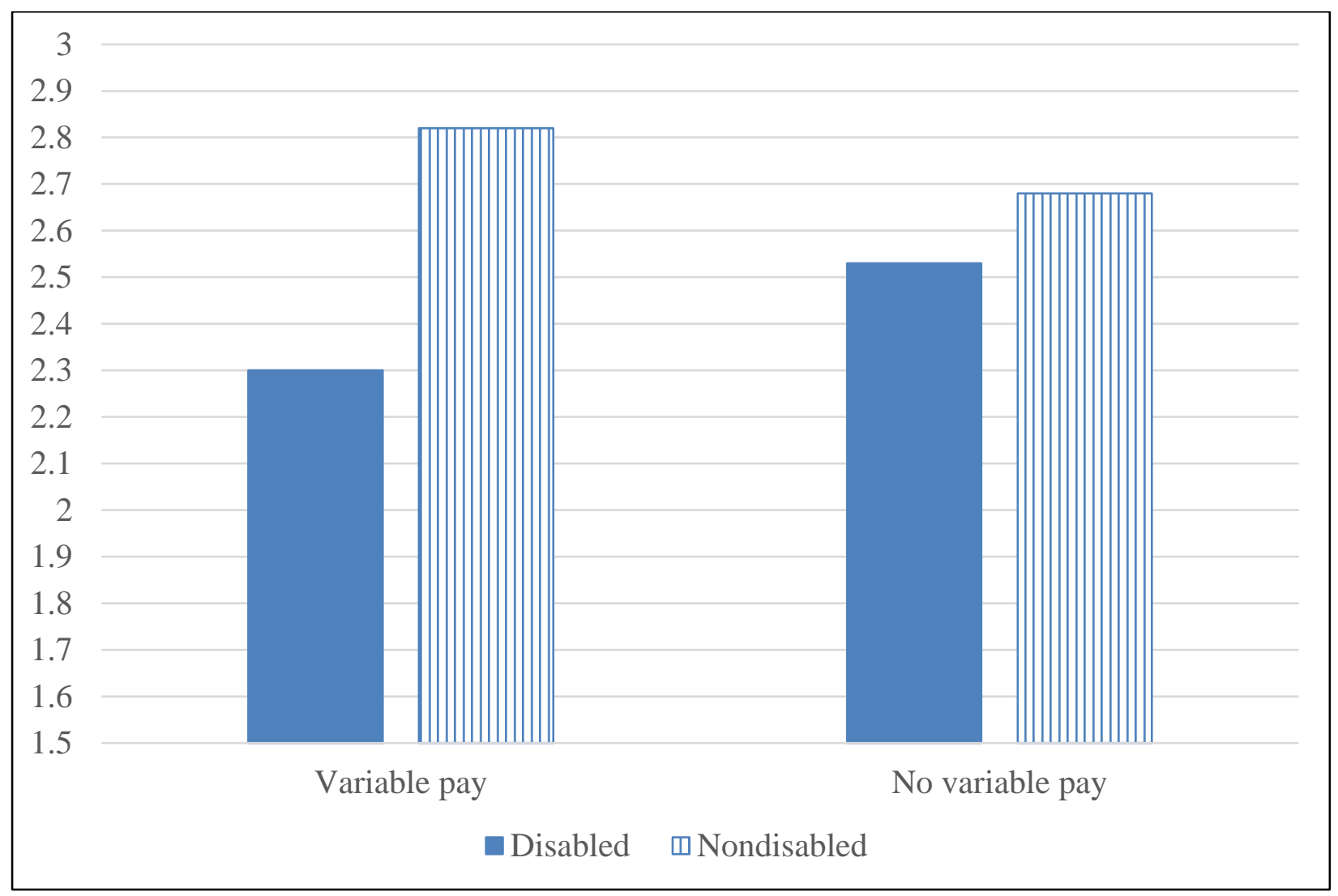


Figure 3. The three-way interaction of individual variable pay, disability status and trust in management on pay satisfaction

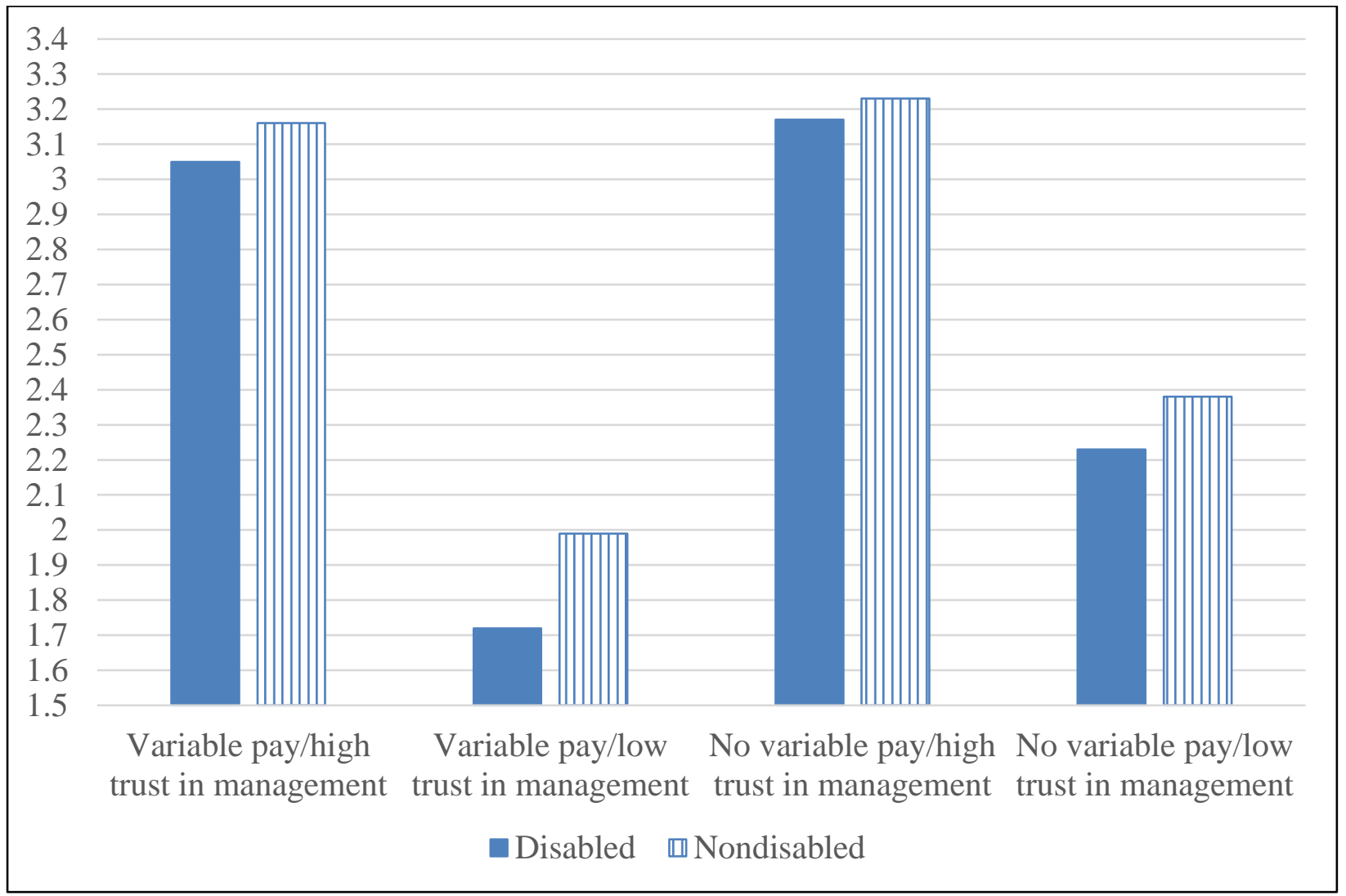


Figure 4. The three-way interaction of individual variable pay, disability status and disabilityrelated HRM practices on pay satisfaction when disability policy exists

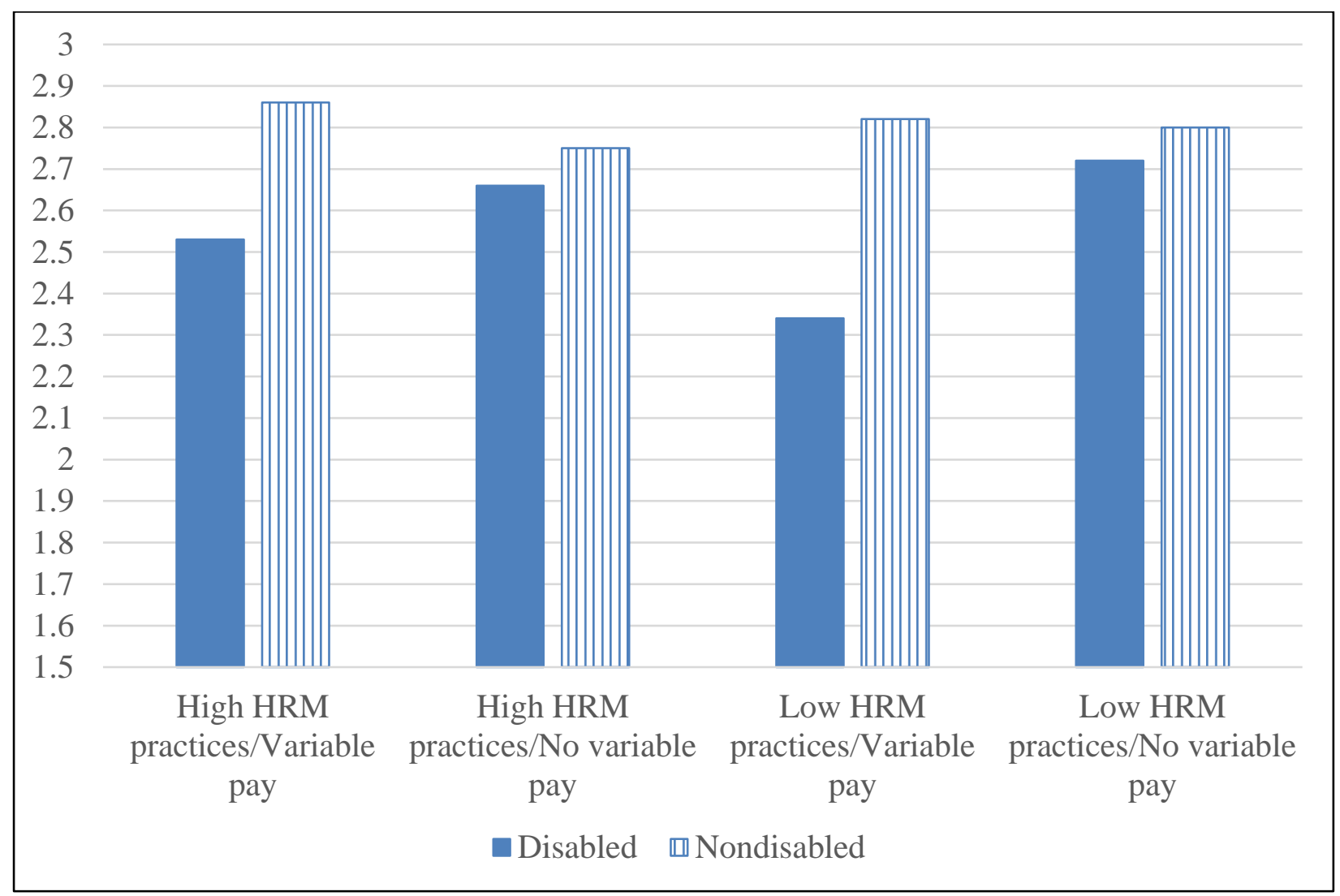




\section{Author Biographies}

Amanda Shantz is a Reader in Organisational Behaviour and Human Resources at the University of Greenwich. Her research interests include work engagement, human resource management practices, and the nonprofit sector. Her research has appeared in journals such as European Journal of Work and Organizational Psychology, Human Relations, Human Resource Management, Human Resource Management Review, International Journal of Human Resource Management, and Organizational Behavior and Human Decision Processes.

Jing Wang is an Associate Professor of Human Resource Management at York University, Canada. Her research interests include strategic human resources management, work-life balance, workplace diversity, and underemployment. Her work has received the Academy of Management and the Labor and Employment Relations Association Best Paper Award and appeared in journals such as Human Resource Management, International Journal of Human Resource Management, and International Journal of Manpower.

Amina Malik is an Assistant Professor of Human Resource Management at Trent University in Oshawa, Canada. Her primary research areas include talent management, socialization of cultural minorities, leadership, and other emerging issues in human resource management. Her research has been published in several high-impact journals such as Human Resource Management Review, International Journal of Cross Cultural Management, and European Business Review, among others. 